NBER WORKING PAPER SERIES

\title{
DO SCHOOL-TO-WORK PROGRAMS HELP THE "FORGOTTEN HALF"?
}

David Neumark

Donna Rothstein

Working Paper 11636

http://www.nber.org/papers/w11636

\section{NATIONAL BUREAU OF ECONOMIC RESEARCH 1050 Massachusetts Avenue \\ Cambridge, MA 02138 \\ September 2005}

Neumark is Senior Fellow, Public Policy Institute of California, Research Associate, NBER, Research Fellow, IZA, and Visiting Scholar, Institute of Business and Economic Research, UC-Berkeley. Rothstein is Research Economist, Bureau of Labor Statistics, U.S. Department of Labor. We are grateful to Chris Jepsen and Heather Rose for helpful comments. The views expressed herein are those of the author(s) and do not necessarily reflect the views of the National Bureau of Economic Research.

(C)2005 by David Neumark and Donna Rothstein. All rights reserved. Short sections of text, not to exceed two paragraphs, may be quoted without explicit permission provided that full credit, including $\odot$ notice, is given to the source. 
Do School-To-Work Programs Help the "Forgotten Half"?

David Neumark and Donna Rothstein

NBER Working Paper No. 11636

September 2005

JEL No. I28, J15, J24

\section{$\underline{\text { ABSTRACT }}$}

This paper tests whether school-to-work (STW) programs are particularly beneficial for those less likely to go to college in their absence - often termed the "forgotten half" in the STW literature. The empirical analysis is based on the NLSY97, which allows us to study six types of STW programs, including job shadowing, mentoring, coop, school enterprises, tech prep, and internships/apprenticeships. For men there is quite a bit of evidence that STW program participation is particularly advantageous for those in the forgotten half. For these men, specifically, mentoring and coop programs increase post-secondary education, and coop, school enterprise, and internship/apprenticeship programs boost employment and decrease idleness after leaving high school. There is less evidence that STW programs are particularly beneficial for women in the forgotten half, although internship/apprenticeship programs do lead to positive earnings effects concentrated among these women.

David Neumark

Public Policy Institute of California

500 Washington Street, Suite 800

San Francisco, CA 94111

and NBER

neumark@ppic.org

Donna Rothstein

Bureau of Labor Statistics

2 Massachusetts Avenue, NE

Suite 4945

Washington, DC 20212

rothstein.donna@bls.gov 


\section{Introduction}

The 1994 Federal School-to-Work Opportunities Act (STWOA) provided more than $\$ 1.5$ billion to support increased career preparation activities in the country's public schools. The STWOA was spurred by a concern that youth labor markets in the United States entailed unnecessary periods of joblessness, excessive job instability, and employment in dead-end jobs (U.S. General Accounting Office, 1990). It therefore aimed to help young people develop the skills needed in the workforce and make better connections to careers through school-to-career transition systems, which fostered partnerships among schools, employers, and others (Office of Technology Assessment, 1995).

The "findings" on which the STWOA was based referred specifically to the problems that disadvantaged and minority youths face in making the school-to-work transition. ${ }^{1}$ Furthermore, schoolto-work practitioners commonly argue that school-to-work programs are particularly helpful for lessadvantaged youths, or the broader group of those who in the absence of any intervention are unlikely to go on to college—often termed the "forgotten half." 2 The main goal of this paper is to use the 1997 National Longitudinal Survey of Youth (NLSY97) to examine evidence on the effectiveness of school-towork programs for the forgotten half—namely, those less likely, ex ante, to attend college. It is important to emphasize that the school-to-work programs covered in the NLSY97 reflect many of the types of programs that the STWOA encouraged, but that the NLSY97 was not designed specifically to evaluate the STWOA. Thus, while there is overlap in programs, there are surely cases of schools that were running school-to-work programs prior to the STWOA, as well as schools that did not receive STWOA funds yet ran related school-to-work programs during the period in which the STWOA was in effect. ${ }^{3}$ Thus, we are evaluating the effects of a variety of school-to-work programs, not the STWOA itself.

\footnotetext{
${ }^{1}$ Specifically, the Act notes that a "substantial number of youths in the United States, especially disadvantaged students, students of diverse racial, ethnic, and cultural backgrounds, and students with disabilities, do not complete high school," and "Federal resources currently fund a series of categorical, work-related education and training programs, many of which serve disadvantaged youths, that are not administered as a coherent whole" (U.S. Congress, 1994).

${ }^{2}$ See, for example, Donahoe and Tienda (1999), and the references therein, and William T. Grant Foundation (1988).

${ }^{3}$ Hamilton and Hamilton (1999) note that the schools and states that appeared to make the most progress toward creating STW systems were those that began building them prior to the STWOA and drew on more resources than
} 
The actual language of the STWOA discussed three approaches to school-to-work (hereafter, STW): work-based learning, school-based learning focusing on careers, and connecting activities between the two types of learning. ${ }^{4}$ The specific STW programs covered in the NLSY97 include: job shadowing; mentoring (matching students to an individual in an occupation); cooperative education (combining academic and vocational studies) ${ }^{5}$ work in a school-sponsored enterprise $;^{6}$ tech prep (a planned program of study with a defined career focus); and internships or apprenticeships. ${ }^{7}$ Among those programs that can be interpreted as work-based learning are job shadowing, cooperative education, work in a schoolbased enterprise, and internships/apprenticeships. Mentoring ideally is also work-based, but may not necessarily involve work. Job shadowing and mentoring are most likely considerably less intensive then these other programs (Neumark and Joyce, 2001). Tech Prep is probably best classified as school-based learning, since it is a curricular arrangement rather than a program based in the workplace. ${ }^{8}$

Our analysis proceeds in two straightforward steps. First, to operationalize the "forgotten half" we estimate a reduced form model for attending college. We do this without incorporating information on STW participation, to establish the ex ante probabilities of college attendance. We use the estimates of this model to distinguish between those in the top half and the bottom half of the distribution of the predicted probability of college attendance, interpreting the latter as the "forgotten half." We then estimate regression models for the effects of participation in various STW programs on a number of postsecondary education- and employment-related outcomes, allowing for separate effects of STW program participation for those in the top and bottom half of the predicted probability of college attendance-in other words, separate effects for the forgotten half. These estimates are then used to test which types of STW programs boost post-secondary outcomes, and which do this particularly for the forgotten half.

those made available by the STWOA. However, Neumark (forthcoming) documents the substantial overlap in one state (California) between programs supported by the STWOA and those covered in the NLSY97.

${ }_{5}^{4}$ See, e.g., http://www.fessler.com/SBE/act.htm (viewed June 26, 2005).

${ }_{6}^{5}$ See Stern, et al. (1997) for a description.

${ }^{6}$ See Stern, et al. (1994).

7 The NLSY97 does not explicitly ask about participation in career academies, although it seems likely that students in career academies would have responded affirmatively to some of the other types of activities included in the STW questionnaire items.

${ }^{8}$ Career academies have a large school-based learning component, but typically also some work-based experiences such as internships. 
The NLSY97 provides researchers with the best opportunity available to date to study the impact of STW, as it covers participation in many types of STW programs, and with the data now available begins to capture post-secondary educational and labor market outcomes. On the other hand, the goal of STW_ "better career decision making" among young men and women completing their education and entering the labor market—is multidimensional, and its fulfillment can only be assessed using long-term observations on career trajectories. Although we cannot yet use the NLSY97 data to observe long-term career trajectories, we can use them to study the early impact of STW programs on the beginnings of the post-secondary STW transitions to employment and/or higher education. We believe that this more limited perspective is still of interest to researchers and policymakers weighing the potential benefits of STW programs. After all, core concerns of STW are moving people into higher-paying jobs, encouraging skill formation among new labor market entrants, and increasing enrollment or employment in the immediate post-high school period.

The results we obtain from the analysis provide some evidence of differences in the effects of the types of STW programs covered in the NLSY97. Specifically, among men in the forgotten half, mentoring and coop programs increase post-secondary education, and coop, school enterprise, and internship/apprenticeship programs boost employment and decrease idleness after leaving high school. For women in the forgotten half, there is less evidence that STW programs are particularly effective, although internship/apprenticeship programs do lead to positive earnings effects concentrated among these women.

\section{Endogenous Selection and Relationship to Previous Research}

A major challenge in studying the effects of STW programs is the traditional concern with inferring causal effects of program participation. The potential for bias from endogenous selection is clear. For example, program participants may be those who already—as high school students—-have the strongest career orientation, and therefore are more likely to work after participating in the program, irrespective of program effects. However, much of the existing literature has, until recently, done relatively little to control adequately for pre-program differences between participants and non- 
participants. The National Center for Research in Vocational Education (NCRVE) provided a thorough compendium of earlier research on STW programs (Stern, et al., 1995). As argued elsewhere, that research provides little if any persuasive evidence of positive impacts of these programs on adult labor market outcomes (Neumark and Rothstein, 2003), often even failing to construct reasonable comparison groups, let alone to consider the problem of selection into the program on the basis of unobserved characteristics that might also be correlated with outcomes. The conclusion that existing work on STW has tended to shy away from trying to draw causal inferences is also reflected in a more recent survey of published academic research on STW across the United States (Hughes, et al., 2001).

Of course, in many respects experimental evidence based on random assignment to STW programs is ideal. To the best of our knowledge, the only such study is the recent (and ongoing) evaluation of career academies by the Manpower Demonstration Research Corporation (Kemple and Snipes, 2000; Kemple, 2001; Kemple, 2004). ${ }^{9}$ The strength of this study is that it is based on random assignment of students to career academies, as participants were chosen randomly from applicants to the career academies in the study, with participants and non-participants followed. This study has found some evidence of positive effects on employment and earnings up to four years after graduation from high school (the study extends no longer at this point), although only for men, and with some hint of possible reductions in post-secondary education. This type of research is clearly valuable, although by its nature it is often restricted to studying only a single type of STW program. Moreover, such experiments are expensive, extremely difficult to implement, and when they depart from their "ideal" setting are prone to problems identified in the literature on the evaluation of other types of social programs (e.g., Heckman, et al., 2000). For both of these reasons, and because of some of the advantages afforded by secondary longitudinal data—including large and representative samples—-we suspect that examination of the effects of STW based on longitudinal micro-data sets such as the NLSY97 will continue to play an important role in assessing the effectiveness of STW programs, and that ultimately the two types of evidence will be complementary.

\footnotetext{
${ }^{9}$ The study covers nine schools across the country, all located in or near urban areas.
} 
This paper studies the impact of STW programs using the NLSY97, a large-scale longitudinal data set with information on participation in a variety of STW programs. With data now extending through Round 5, the NLSY97 provides a view of individuals up to three or four years after leaving high school (or possibly more if they dropped out). In addition, the rich data available in the NLSY97 offer a number of possible approaches to controlling for endogenous selection and hence uncovering the causal impact of STW programs. In addition to simply including very rich sets of control variables including intelligence test scores, information on parents' education and socioeconomic circumstances, and school behaviors, the data set includes questions on subjective probabilities about work and schooling outcomes measured prior to STW participation, as well as repeated observations on individuals in the same school.

In an earlier paper (Neumark and Rothstein, 2003), we used these data in a number of ways to address the issue of biases from endogenous selection into program participation. The overall conclusion was that, in these data, there is little evidence of endogenous selection into STW programs in a manner that biases the estimates of program effects. Estimates of the impact of the various STW programs are quite robust to incorporation of information on prior expectations, or school fixed effects, which provide approaches to controlling for potentially different sources of endogenous selection. Given these earlier results, in this paper we forego all of these types of analyses, and focus instead on standard crosssectional regression estimates-albeit using the very detailed information in the NLSY97 that may, more than anything else, provide sufficient controls for the characteristics on which students select into STW programs. ${ }^{10}$ Readers interested in learning more about the alternative approaches to causal inferences using the NLSY97, and the details regarding the results, are referred to our earlier paper.

To summarize the overall results from the earlier research briefly, however, we found that certain types of programs did have positive effects on either post-secondary education or employment.

Specifically, the evidence indicated that school enterprises boost post-high school education and tech prep may reduce it, while cooperative education and internships/apprenticeships boost post-high school

\footnotetext{
${ }^{10}$ In addition to focusing on the forgotten half, in the present paper we study a considerably broader set of outcomes than in Neumark and Rothstein (2003).
} 
employment. ${ }^{11}$ The magnitudes implied by the estimates were reasonable yet also sizable, suggesting that participation in these programs boosts the probabilities of enrollment or employment by about 0.05 to 0.1 , relative to base probabilities of about 0.5 for college attendance and 0.6 for employment. The STWinduced increases in enrollment and employment largely come about without offsetting decreases in the other activity, suggesting that for those STW programs that boost enrollment or employment, skill formation is on net increased. ${ }^{12}$

Although our previous paper focused on alternative approaches to inferring causal effects of STW programs, it also addressed the question of whether STW programs had differential effects based on race, ethnicity, or other characteristics related to socioeconomic status. For the most part, STW did not appear to be particularly beneficial for disadvantaged students. Instead, the evidence suggested beneficial effects for all groups, although the programs that deliver the benefits vary. One finding that perhaps does stand out, though, is that internship/apprenticeship programs may be particularly advantageous for the lessadvantaged, as these programs boost college enrollment among those with the lowest test scores, and boost employment among blacks and those with less-educated mothers and in non-traditional living arrangements. These findings suggest that further efforts should attempt to establish which populations of students gain more from different types of STW programs. This is the theme we take up in this paper, with an explicit focus on a more specific hypothesis regarding heterogeneity in the effects of STW programs that has been articulated in policy discussions about STW.

\section{$\underline{\text { III. Data }}$}

In the NLSY97, individuals were surveyed about "programs schools offer to help students prepare for the world of work." The six types of programs covered by the survey were listed in the Introduction. A more detailed discussion of the STW questions in the NLSY97 is provided in Joyce and Neumark (2001).

\footnotetext{
${ }^{11}$ There is also some evidence that job shadowing boosts college enrollment, but this finding is not as robust across the alternative statistical analyses.

${ }^{12}$ Neumark and Joyce (2001) attempted to evaluate the effects of STW using only the first round of the NLSY97, but given the newness of the data set they were restricted to estimating effects on work- and education-related expectations of high-school students.
} 
The analysis is based on data from the first five rounds of the NLSY97. When the first round was administered, in 1997, respondents were aged 12-17. ${ }^{13}$ In Round 1, the STW questions covered the types of programs in which individuals participated (at all and most recently), whereas in subsequent rounds the questions shifted to participation in the past year. The questions were asked of all $9^{\text {th }}$ to $12^{\text {th }}$ graders in Round 1. In Rounds 2-5 the questions were asked of any respondents enrolled in school (including college), although we focus on participation while in high school by only using STW information for years in which respondents were enrolled in high school. ${ }^{14}$ With the second round, in 1998, we can begin to observe some respondents who have left high school, but we get many more such observations with the third through fifth rounds, and therefore focus on post-secondary educational and employment outcomes measured as of the third, fourth, or fifth round. ${ }^{15}$

Table 1 gives some idea of the breakdown of the sample. Of the total 8,984 original respondents to the NLSY97, 8,609 were interviewed in 1999, 2000, or 2001 (Rounds 3-5). ${ }^{16}$ Of these, attention is restricted to those aged 18 or older, which eliminates about 1,800 observations, and to those respondents with at least one post-high school observation in 1999, 2000, or 2001, yielding 5,966 observations. We restrict the sample in this way to isolate those individuals for whom at least the initial years of their

\footnotetext{
${ }_{13}^{13}$ Respondents were aged 12-16 as of December 31, 1996.

${ }^{14}$ The manner in which the STW data are collected raises two issues. First, because some (and most likely the larger share of) STW participation occurs in the later high school years, we cannot use the NLSY97 to study the effects of STW on high school completion. Because high school dropouts would by construction report less STW participation, there would be a spurious negative correlation between STW participation and dropping out of high school. Second, a moderate share of individuals report some college enrollment in the last year in which they are enrolled in high school, so in principle these individuals could be reporting STW during their short initial spell of college. In past work, we have examined the sensitivity of the results to excluding the STW information for that interview year when calculating our STW measures, and found that our qualitative conclusions were unaffected.

${ }^{15}$ Post-secondary enrollment is based on the NLSY97's definition of "regular schooling." This refers to enrollment in a college, graduate school, law school, or nursing program leading to an $\mathrm{RN}$ degree, but not training in technical institutes, programs for trade licenses, etc., unless the credits can be transferred to a regular school and would count toward a diploma or degree.

${ }^{16}$ Like any longitudinal study, the NLSY97 suffers from some attrition, as indicated by the dropoff in interviews. In general, though, the National Longitudinal Surveys have been very successful at following cohort members over time. It is quite plausible that attriters differ from non-attriters with respect to their STW transitions-for example, those who become idle after leaving high school may be more like to attrit. However, only if attriters differ from non-attriters with respect to the effects of STW will the parameter estimates of interest be biased. This question can be explored using methods paralleling those in Falaris and Peters (1998), who test for attrition bias by comparing estimates of behavioral equations of "eventual" attriters and non-attriters in the period prior to attrition of the former. However, such an analysis will not be useful for the NLSY97 until quite a few more rounds of data are available.
} 
employment or higher education after leaving high school is available. In future research, we will study the longer-term career trajectories of STW participants and non-participants.

In addition to meeting these criteria, information on STW participation is also required. In order to get an accurate reading on STW participation during high school, and to be able to measure some behaviors as of a well-defined date prior to the STW participation we study, we focus mainly on the STW information provided in the surveys after the first round in 1997, which cover participation in the past year. ${ }^{17}$ Requiring STW information after Round 1 drops sample observations for those who did not answer the STW part of the survey after this round, either because they had not spent time in high school in 1997 or a subsequent year, or in subsequent years were not enrolled as of the interview date and hence were not asked the STW questions. ${ }^{18}$ Coupled with some final sample restrictions on availability of the other data used in the study, this takes us down to 4,810 observations. For our baseline analysis sample, we also exclude private schools, which are not the focus of STW policy, and vocational schools, which in a sense offer nothing but STW. This leaves us with 4,292 observations.

Finally, while some of the analyses are based on the respondent's activities as of the first posthigh school interview, others are based on longitudinal information beginning after high school, from continuous record files included in the NLSY97. We require that respondents have information available for at least one year following the September after which they left high school, and we use as much data as possible. The minimum requirement leaves us with a smaller sample of 2,855 for these analyses.

\section{$\underline{\text { IV. Empirical Approach }}$}

\footnotetext{
${ }^{17}$ The school behaviors are measured as of Round 1. This approach also helps avoid the problem of early STW participation affecting the Armed Services Vocational Aptitude Battery (ASVAB) test scores that we use as controls. The ASVAB was administered in 1997 or 1998, so at worst this leaves open the possibility of some overlap between the period to which Round 2 STW questions refer and time prior to the administration of the ASVAB.

${ }^{18}$ The implication of using the data on STW participation in this way is that we ignore variation in participation reported in Round 1. If past participation has an effect and is associated with future participation, then this introduces a source of correlation between the STW participation that we measure and the error term. However, we are not too concerned about the potential bias that this creates, since it is generated from a correlation of the treatment variable with past STW participation, rather than with something that might spuriously generate an effect (or lack thereof) of STW. In addition, in our past work we have verified the robustness of the results to using information on any STW in which the respondent had ever participated.
} 
The basic approach with which we begin, and on which we build, is to estimate, at the individual level, the relationship between various work-related or education-related measures in the post-high-school period and participation in STW. ${ }^{19}$ STW participation is categorized in terms of participation in the six specific types of programs discussed earlier. Generically, let $\mathrm{Y}_{\mathrm{i}}$ be the work- or education-related measure for individual $\mathrm{i}$, let $\mathrm{STW}_{\mathrm{i}}$ be a vector of dummy variables for whether the individual reports participating in each STW program, and let $\mathrm{X}_{\mathrm{i}}$ be a vector of controls. We estimate models of the form:

$$
\mathrm{Y}_{\mathrm{i}}=\alpha+\mathrm{STW}_{\mathrm{i}} \beta+\mathrm{X}_{\mathrm{i}} \gamma+\varepsilon_{\mathrm{i}}{ }^{20}
$$

The parameters of interest are $\beta$. Consistent estimation of $\beta$ requires that $\varepsilon_{\mathrm{i}}$ be uncorrelated with the controls in $\mathrm{X}_{\mathrm{i}}$ as well as with $\mathrm{STW}_{\mathrm{i}}$. As noted earlier, Neumark and Rothstein (2003) fully explores potential biases in the NLSY97 from endogenous selection into STW program participation that could generate a correlation between $\varepsilon_{\mathrm{i}}$ and the independent variables. That study finds little if any evidence of such biases from using school fixed effects or including controls for expectations prior to STW participation. Because either of these approaches limits the data set (for example, the expectations variables were asked only of a subsample), in this paper we rely instead on the full sample.

A good part of the reason for these earlier findings may be that the NLSY97 offers a rich and detailed set of control variables for characteristics of both individual respondents and their families. In addition to fairly typical demographic controls (sex, race, ethnicity, and age), the data set includes three additional sets of control variables that we view as potentially important. These include data on: living arrangements and the respondent's family (including urban residence, whether one lives with both biological parents, only the biological mother or father, a biological parent and a step parent, or in some

\footnotetext{
${ }^{19}$ When we define employment, those who report their employer as the military are coded as employed.

${ }^{20}$ When the dependent variable is dichotomous, in the models for the effects of STW participation we report linear probability estimates. We verified that results were very similar using logit or probit models. Using the linear probability model simplifies the presentation and avoids distributional assumptions that underlie the logit or probit model. Throughout the empirical analysis, reported standard errors are robust to heteroscedasticity. Also, because there are often multiple observations on students within the same school, the reported standard errors allow for heteroscedasticity of the error term across schools and non-independence of an arbitrary nature within schools, which typically results in somewhat larger standard errors.
} 
other arrangement, as well as information on household size, household income, ${ }^{21}$ and the biological mother's schooling); ASVAB test scores; and self-reported measures of school behavior (whether the respondent was threatened at school, or had gotten into a physical fight at school, and whether the respondent had been late with no excuse two or more times, or absent two or more weeks, all measured in 1997). This rich array of variables seems likely to capture many sources of variation in underlying propensities for post-high school enrollment or employment, including the quality and quantity of human capital investments in children, resources available in the household, educational norms in the family, labor market networks, the individual respondent's academic ability, and the extent to which the respondent is learning traits such as timeliness and reliability that are valued by employers.

Given the earlier evidence that including a detailed set of control variables appears to be sufficient, and given that the question we ask in this paper demands more of the data by testing for heterogeneity in the effects of STW programs, we do not revisit the alternative approaches to testing for biases from endogenous selection, but simply work with the fullest set of control variables available for the full sample. These are listed explicitly in Tables 2A and 2B. Moreover, even these control variables tend to be largely uncorrelated with STW program participation. This evidence is reported in these tables, in the form of linear probability estimates for participation in each of the six types of STW programs, estimated separately by sex.

The tables present, in the first row, the proportions of students participating in each type of program covered in the individual survey, and in the remaining rows the linear probability estimates for participation in each type of program. The results indicate that very few variables are significantly related to STW participation, aside from what might be considered a smattering of estimated coefficients the statistical significance of which could just reflect randomness. ${ }^{22}$ The finding that very few variables

\footnotetext{
${ }^{21}$ Household income is from Round 1, and is from the parent questionnaire except in the rare event that the youth is defined as independent in 1997.

${ }^{22}$ The one exception, perhaps, is the black-white differences. Neumark and Rothstein (2003) also found some evidence of higher STW participation for blacks. The evidence suggested that this is a within-school phenomenon, as there was no significant evidence that schools with more black students were more likely to offer STW. At the same time, evidence in that paper did not point to particularly stronger benefits of STW program participation for blacks, with the exception of internship/apprenticeship programs.
} 
predict STW participation reinforces the conclusion that problems from endogenous selection into STW participation may be minimal. ${ }^{23}$

Our particular interest in this paper, however, is in the effects of STW programs on the forgotten half and how these effects contrast with those for the rest of the population. We first estimate a probit model for whether the respondent attended college (two- or four-year) at any time after leaving high school (including currently), insofar as we can observe this in our data. This model includes the same set of control variables used in the preceding table and in the models for estimating the effects of STW program participation that follow. We then use this model to rank the predicted probability of college attendance and distinguish between those in the bottom and top halves of the distribution of predicted probabilities. We use sample weights in computing the median of this distribution, so that our approach identifies those whose predicted probabilities of college attendance are in the bottom half of the population distribution, not the sample distribution. In doing this, we do not include STW participation in the college attendance model. This better aligns our approach with what might be viewed as a policy intervention of identifying those who, ex ante, have lower probabilities of college attendance, and then asking what the benefits of STW would likely be for a subpopulation chosen this way-in particular, those in the bottom half of the ex ante distribution. A more complete model of college attendance might include STW participation, but that is a different exercise from identifying which individuals are more or less likely to attend college absent STW programs.

From the estimates of the model of college attendance, we construct an indicator for those in the bottom half of the distribution of predicted probabilities, denoted $\mathrm{FH}_{\mathrm{i}}$ (for "forgotten half"). We then estimate models of the form:

$$
\mathrm{Y}_{\mathrm{i}}=\alpha+\mathrm{STW}_{\mathrm{i}} \beta+\mathrm{STW}_{\mathrm{i}} \cdot \mathrm{FH}_{\mathrm{i}} \beta^{\prime}+\mathrm{X}_{\mathrm{i}} \gamma+\delta \mathrm{FH}_{\mathrm{i}}+\varepsilon_{\mathrm{i}}
$$

\footnotetext{
${ }^{23}$ One potential issue is that the ASVAB test scores may appear insignificant because of a high degree of multicollinearity among them. Tests for the joint significance of the test score coefficients-which are not affected by the multicollinearity-indicated that multicollinearity is not an important issue, as it was rare for the joint test to indicate significance when none of the individual tests did. More generally, collinearity among the other variables in the models in Tables $2 \mathrm{~A}$ and $2 \mathrm{~B}$ could obscure significant coefficients. But the R-squares are also extraordinarily low, ranging from 0.010 to 0.022 . These may be low in part because of the dichotomous nature of the dependent variable. But in our earlier paper we found much higher R-squares for regressions for school-level offerings of STW programs as functions of school characteristics.
} 
Using estimates of models of this form, we can address a couple of different questions. First, whereas estimates of $\beta$ in equation (2) capture the effects for those in the upper half of the distribution of the predicted probability of college attendance, the estimates of $\beta$ ' capture the differences between the effects of STW programs for the forgotten half and the rest of the sample, so the statistical significance of these estimates provides a test for differences in the effects. Second, the estimates of $\left(\beta+\beta^{\prime}\right)$ capture the overall effects of STW programs for those in the forgotten half, and the significance of these summed coefficient estimates indicates whether there are effects for this subpopulation. The tables that follow report results regarding both types of estimates, and then present a summary of the effects of STW programs overall, the effects for the forgotten half, and how the effects differ for the forgotten half.

\section{$\underline{\text { V. Results }}$}

\section{Homogeneous Effects of STW Participation}

We begin by briefly discussing estimates of equation (1), which excludes the direct indicator for being in the forgotten half and its interactions with STW participation. These estimates expand upon many of the findings reported in Neumark and Rothstein (2003) in two ways. First, we use an additional round of NLSY97 data, and hence more observations and later ones. Second, we expand the set of outcomes considered. Previously, we restricted attention to transitions to higher education or employment, studying only the impact of STW programs on whether respondents were employed or had enrolled in higher education as of the first post-high school interview. Here, we also study whether the respondent attended a two-year or four-year college, whether the respondent was currently enrolled in either type of college, whether the respondent had participated in a training program, and whether the respondent was currently idle (neither working nor enrolled currently). More significantly, we use the additional data afforded by Round 5 of the NLSY97 to construct longitudinal measures of time spent in different activities, and to measure early labor market outcomes. Specifically, we study the proportion of weeks since leaving high school spent in college, working, or idle, and average hours worked over all 
weeks. ${ }^{24}$ In addition, we study earnings and wages, as well as whether the person is working full-time, for the most recent job in which the respondent is observed. We study all of these outcomes in the subsequent analysis of differences in STW outcomes for the forgotten half, as well. Finally, in contrast to our previous paper, here the results are all reported disaggregated by sex.

The results are reported in Tables 3-5. Table 3 reports the results for the various outcomes defined as of the first post-high school interview, which gives us a sense of the post-secondary transitions associated with STW programs (the sole focus of our earlier work). The control variables included are the same as those in Table 2. The first four columns in Table 3 are for alternative measures of postsecondary education. For females, in the top panel, we find that job shadowing has a significant positive effect on current enrollment and on attending a two-year college, but not on the other two measures of education. Mentoring, on the other hand, has significant positive effects on all of the education measures with the exception of attendance at two-year colleges. In contrast, coop programs appear to reduce attendance at four-year colleges, but to boost attendance at two-year colleges, while school enterprise programs have a weak positive effect on the likelihood of any enrollment. Except for education at twoyear colleges, tech prep appears to rather unambiguously reduce post-secondary education (although only two of three effects are significant). Finally, internship/apprenticeship programs appear to boost the likelihood of any college attendance as well as four-year college attendance. Thus, with the exception of tech prep, many of the STW programs appear to increase post-secondary education for women, although the effects differ across programs - in particular, with respect to two-year vs. four-year college attendance. The effects are often sizable — for example, with effects often in the range of 0.05 to 0.07 (in absolute value), relative to mean attendance or enrollment rates on the order of 0.2 to 0.5 .

The results in columns (5)-(7) capture current work, training, and idleness. Here there are virtually no significant effects for women, with a couple of exceptions. ${ }^{25}$ Most significantly, perhaps,

\footnotetext{
${ }^{24}$ This is computed on a weekly basis, with zeros for weeks with no work; the average over all weeks is then computed. When we estimate equation (1) for these longitudinal measures, we include a control for the total number of weeks from the first September after leaving school until the interview.

${ }^{25}$ Note that a program that affects schooling (such as mentoring) need not have offsetting effects on work, because individuals can engage in both work and schooling.
} 
tech prep—which was associated with less post-secondary schooling—has a positive effect on the likelihood of participating in a training program, suggesting that tech prep leads to some substitution among opportunities for further learning.

The bottom panel reports results for men. There are quite a few similarities. As for women, there is some evidence for men that job shadowing, mentoring, and school enterprise programs increase postsecondary education, but tech prep reduces it. The magnitudes are in the same range as for women. ${ }^{26}$ However, no effects of internship/apprenticeship programs on schooling are apparent for men, while school enterprise programs have rather strong positive effects (in contrast to limited evidence of positive effects for women). ${ }^{27}$ There are also some sharper differences regarding the effects of STW programs on work, training, and idleness, as reported in columns (5)-(7). First, as for women, tech prep increases the likelihood of participating in a training program. However, for men, in contrast to women, some STW programs appear to boost employment and correspondingly to decrease idleness. This is the case for coop programs (which also increase training participation) and for internship/apprenticeship programs. The estimated employment effects are about 0.09 , relative to an employment rate of 0.61 . The corresponding negative effects on idleness are about the same magnitude but represent large percentage declines (by about one-third).

Table 4 reports results for the longitudinal measures of the percentage of weeks in school, working, or idle, as well as average hours. The education results for women do not parallel very closely the enrollment results from Table 3. Indeed, only for school enterprise programs is there a significant effect (positive) on the proportion of weeks spent in school, whereas this type of program had among the weaker positive effects in Table 3. Similarly, in this table there is stronger evidence that STW programs boost employment for women, with job shadowing and coop programs boosting weeks of work, and coop

\footnotetext{
${ }^{26}$ One striking finding is that the effects of job shadowing and mentoring appear relatively large, despite these program being considerably less intense in terms of hours devoted to them than, for example, coop or internship/apprenticeship programs. That could indicate problems with the data, or that the effectiveness of different programs is not that closely related to the intensity of the programs.

${ }^{27}$ Research by Stern (1984) and Stern, et al. (1994) reports that enterprise-based jobs are more closely related to students' education than are out-of-school jobs, and that enterprise-based jobs provide more opportunity to apply what students are learning in school; so school enterprises may be a particular type of STW program that enhances the educational experience and therefore encourages higher education.
} 
programs also boosting average hours. For men, as well, the schooling evidence does not line up very well with Table 3, with a positive effect on schooling apparent only for job shadowing programs. In contrast, coop, school enterprise, and internship/apprenticeship programs all have significant positive effects on weeks worked (and the latter two also reduce idleness), and coop programs and tech prep appear to boost average hours. Thus, the longitudinal measures, which seem that they should be more informative because they are not based on a single snapshot, tend to weaken the evidence of STW effects on schooling, but to reinforce and perhaps strengthen the evidence of positive employment effects. ${ }^{28}$ For the employment-related outcomes, the estimated effects of STW participation are somewhat more moderate than those in Table 3, but still sizable. For example, for both men and women, participation in coop programs boosts the share of weeks worked by about five percentage points, an increase of a bit less than ten percent. And the negative effect on idleness of internship/apprenticeship programs for males is still over 25 percent.

Table 5 turns to measures related to the quality of employment on the most recent job (for those observed employed), including earnings and wages as well as full-time status. The results for wages and earnings are reported both without and with conditioning on schooling, experience, and full-time status, with the idea being that the unconditional estimates capture the full effects of STW programs including those acting through schooling, experience, etc. For women, in the top panel, many of the programs that were associated with increased schooling or work appear to have less effect on characteristics of the most recent job. Mentoring programs, which increase education for women based on the estimates in Table 3, if anything reduce wages and full-time status, although it is conceivable that this is partly attributable to

\footnotetext{
${ }^{28}$ One possible explanation for this is that the continuous history files capture schooling experiences with more error, although it is not obvious why this would be the case, and we leave it to future work to explore this possibility more fully. Another possibility is that estimates are biased because of the incidence of zeros for the dependent variables. We re-estimated the models in Table 4 (and Table 8, which studies the same dependent variables distinguishing effects for those in the forgotten half) using Tobits. In most cases the results were very similar. Finally, we considered the possibility that the results in Table 4 are weaker because of the smaller sample. Re-estimating the models in Table 3 for the Table 4 sample did in fact point to weaker effects of STW participation than indicated in Table 3 (and similarly for the models with the forgotten half interactions that come later). Our best estimates come from using the largest sample possible. What this indicates, then, is that we may need more rounds of the NLSY97 to better pin down the effects of STW on the longer-term measures of postsecondary outcomes, something we will pursue in future research.
} 
combining work with schooling, given the young ages of respondents. Only coop programs (weakly) and internship/apprenticeship programs (much more strongly) appear to increase wages and earnings. For men, as well, many of the effects of STW programs do not carry over to the job, as it is only coop programs that appear to increase wages. These results must be interpreted cautiously, however, as they pertain to jobs held early in the life-cycle, and may be contaminated by such factors as ongoing schooling and lower current wages associated with greater opportunities for human capital investment.

\section{STW Effects for the Forgotten Half}

Having examined the evidence on the overall effects of STW programs, we now turn to the core of our new analysis, examining how effects differ for those who are less likely, ex ante, to attend college—or for the "forgotten half." Table 6 presents the results from the first step in this analysis, estimates of models for the likelihood of college attendance (excluding information on STW participation). These estimates are used to compute the probability of college attendance for each respondent in the sample. ${ }^{29}$

These estimates do not contain any surprises. Blacks are more likely to attend college, which is not true in the raw means but is not an uncommon result conditional on socioeconomic status, test scores, etc. (e.g., Cameron and Heckman, 2000). Those respondents living with their biological mother only, and more generally those living in an arrangement other than with two biological parents, are considerably less likely to attend college, which may partly reflect socioeconomic status. For males, household size is negatively associated with college attendance, while both male and female respondents with moreeducated mothers are more likely to attend college. Test scores are positively associated with college attendance, especially the math knowledge score on the ASVAB. Finally, troublesome school behaviors including both violence and absences are generally associated with a lower likelihood of college

\footnotetext{
${ }^{29}$ Although we report linear probability estimates for our outcomes (as in Tables 3-5, thus far), here we somewhat arbitrarily use a probit model. For the classification of who is in the forgotten half, it should matter little which model we use, and we verified that the results were robust to using a linear probability model in Table 6 instead. We prefer the linear probability model for the key outcomes, since in the probit model consistency and asymptotic inference rely on the correct specification of the error distribution.
} 
attendance. In general, these models predict college attendance correctly (based on the predicted probability being above or below the median) in a high fraction of cases—between 71 and 74 percent.

The next three tables report models for the same outcomes covered in Tables 3-5, but now expanded to include the indicator for whether the predicted probability of college attendance-based on the estimates in Table 6-was below the median, and its interaction with the dummy variables for participation in each type of STW program (equation (2)). ${ }^{30}$ Table 7 covers the education- and workrelated outcomes as of the first post-high school interview; Table 8 covers the longitudinal measures of schooling, work, idleness, and hours; and Table 9 covers wages, earnings, and full-time status on the most recent job. In each of these tables, the main effects of STW programs $(\beta)$ measure the effects for those in the top half of the distribution of predicted probabilities, while the interactive coefficients $\left(\beta^{\prime}\right)$ measure the difference in the effects for the bottom half. For each STW program the sum of these-not reported in the table, but summarized later-measures the effect for those in the forgotten half. However, in the tables the statistical significance of the results for those in the forgotten half is reported in two ways. First, with asterisks we denote whether the interactive coefficients are significantly different from zerothat is, whether the effects of STW programs are different for those in the forgotten half. And second, with plus signs we denote whether the overall effects for those in the forgotten half $-(\beta+\beta$ ') in equation (2)—are significantly different from zero.

The estimates in the top half of Table 7, for women, indicate that the effects of mentoring and internship/apprenticeship programs on post-secondary schooling persist in the main effects, and appear no different for the forgotten half. The main effects of coop programs are if anything stronger (on attending four-year and two-year colleges), but are weaker for those in the forgotten half. In contrast, the adverse effects of tech prep on schooling are clearly stronger for those less likely, ex ante, to attend college. In the four outcomes covered in columns (1)-(4), there are only a couple of cases where plus signs indicate statistically significant effects for the forgotten half—namely, for the positive effects of job shadowing on

\footnotetext{
${ }^{30}$ We also estimated augmented models in which we included interactions between the forgotten half indicator and all of the other control variables, to be sure we were not picking up omitted interactions in the forgotten half-STW interactions. The results were very robust to the inclusion of these interactions.
} 
current enrollment and on attending a two-year college, and the negative effect of tech prep on college attendance. Otherwise, the absence of plus signs implies no evidence of significant effects of STW programs for the forgotten half.

As in Table 3, for women there is not much evidence of effects of STW on current work, training, and idleness. There is evidence that the positive effect of coop programs on current employment is not present for those less likely to attend college, as the estimated interactive effect is negative and significantly different from zero. On the other hand, there is evidence that job shadowing reduces idleness only for those in the lower half of the distribution of the predicted probability of college attendance, consistent with the increased schooling for these respondents evident in columns (2) and (4).

For men, there is stronger evidence of different effects of STW programs for the forgotten half. The first four columns indicate that mentoring, coop, and internship/apprenticeship STW programs boost post-secondary education only for the forgotten half, while school enterprise programs tend to have positive main effects as well. In the last three columns, there is evidence that coop programs increase employment overall and for the forgotten half, but coop programs decrease idleness only for the forgotten half. Similarly, the effects of internship/apprenticeship programs in increasing employment and reducing idleness are quite strong, with the employment effect present only for those less likely to attend college.

The evidence on the longitudinal measures of schooling, work, idleness, and hours, is reported in Table 8. For women, the evidence appears weaker, as there is only one case of a significant effect for the forgotten half — for the effect of coop programs on hours — and the effect is small. For men, though, paralleling the previous table, there is stronger evidence. In particular, we now find that school enterprise programs reduce idleness only for the forgotten half, while internship/apprenticeship programs boost the proportion of weeks worked only for this part of the sample.

Table 9 turns to the analysis of effects on wages, earnings, and full-time status. For women, the one set of results that stands out is that internship/apprenticeship programs boost wages and earnings (unconditional and conditional) for those in the forgotten half only. For men, there is little evidence of effects of STW programs on these outcomes, paralleling the simpler analysis in Table 5. 


\section{Summary of the Findings}

The three preceding tables present a large number of estimates, and it is difficult to get a sense of their overall message by perusing the tables. Therefore, in Table 10 we offer a summary of the results from Tables 7-9. In columns (1) and (3) we summarize the results for the forgotten half, and in columns (2) and (4) we summarize the results for those in the top half of the distribution of the predicted probability of college attendance. We list all effects that are significantly different from zero for the forgotten half. Plus signs indicate a positive effect and minus signs a negative effect. These signs appear three, two, or one time depending on whether the result is significant at the one-, five, or ten-percent level. For the estimates for the forgotten half, we also distinguish two important cases. First, if the evidence points to effects that are significant only for the forgotten half (or significant with the opposite sign compared to the top half), the result is reported in boldface. Second, for the subset of these cases where the estimate for the forgotten half was significantly different from that for the rest of the samplethat is, where we reject equality for the two halves of the sample - the entry is underlined as well. Both of these types of results are of interest; the first indicate that for the forgotten half, only, the effects are significant or of a particular sign; the second set indicate the stronger result that the effects are significantly stronger for the forgotten half.

Looking first at the results for women, for the schooling-related outcomes the impression given by Table 10 is that STW programs are generally less effective for those in the forgotten half. There are considerably more significant effects for those in the top half, with generally positive effects for mentoring, school enterprise, and internship/apprenticeship programs. And the negative effects of tech prep on post-secondary education appear for both halves of the distribution. The findings are somewhat different for the job-related outcomes, with evidence that internship/apprenticeship programs boost wages and earnings for the forgotten half-and only for the forgotten half.

For men, there is more evidence of beneficial effects of STW programs on those in the forgotten half. For the schooling-related outcomes, there are roughly equal numbers of significant effects in the two halves of the distribution of predicted probabilities of college attendance. But note that for those in 
the forgotten half these effects are almost always positive (with the exception of internship/apprenticeship programs, which reduce attendance at 4-year colleges but boost it at 2-year colleges). In contrast, for those in the top half, many more of the estimated effects on post-secondary schooling are negative. Similarly, for the job-related outcomes there is particularly strong evidence that internship/apprenticeship programs boost employment and decrease idleness among men in the forgotten half, with similar results for coop and school enterprise programs (although coop programs and tech prep also boost employment for those in the top half). At the same time, there are some other effects of STW participation that are more concentrated among men in the top half, in particular for job shadowing and tech prep.

Overall, then, this summary points to some evidence that STW programs are particularly advantageous for men in the forgotten half, but not for women. Among the strongest evidence for men in the forgotten half is that mentoring and coop programs increase post-secondary education, and that coop, school enterprise, and internship/apprenticeship programs boost employment and decrease idleness.

\section{$\underline{\text { VI. Conclusions }}$}

This paper tests whether school-to-work (STW) programs are particularly beneficial for those less likely to go to college in their absence-often termed the "forgotten half" in the STW literature. The empirical analysis is based on the NLSY97, which provides the best data available to date on participation in a wide array of STW programs. The NLSY97 data allow us to study six types of STW programs, including job shadowing, mentoring, coop, school enterprises, tech prep, and internships/apprenticeships.

The data provide some evidence that STW program participation is particularly advantageous for men in the forgotten half. Among these men, mentoring and coop programs increase post-secondary education, and coop, school enterprise, and internship/apprenticeship programs boost employment and decrease idleness after leaving high school, ${ }^{31}$ while there is less evidence of such beneficial effects for other men. The evidence that STW programs are particularly beneficial for women in the forgotten half is

\footnotetext{
${ }^{31}$ Because these results for the effects of STW on idleness appear mainly for men, we doubt that they reflect substitution between work and parenting.
} 
limited to findings that internship/apprenticeship programs lead to positive earnings effects-measured early in the life cycle-concentrated among these women.

Overall, then, especially for men there is rather compelling evidence that participation in some STW programs increases education and employment and decreases idleness among the forgotten half. Returning to the policy issue that helped frame this paper, these findings suggest that there may be substantial benefits to STW efforts targeted towards those male high school students whose characteristics and backgrounds make them less likely to attend college.

There are, of course, some qualifications to these conclusions, or further clarifications that are necessary. First, the empirical analysis in this paper only weighs some of the benefits of a set of programs. It does not consider the costs of these programs, nor does it compare the benefits with the potential benefits of other programs. For example, while we posed the question as addressing, in part, whether national policy changes downgrading STW efforts and emphasizing testing might not serve the forgotten half, we have not presented evidence that test-based reforms are not particularly helpful to those in the forgotten half. ${ }^{32}$ Second, as noted in the text, we have not revisited all of the issues of endogenous selection that we studied in our earlier paper (Neumark and Rothstein, 2003) in analyzing the effects of STW programs on a more limited set of outcomes. In that paper, we found that biases from endogenous selection into STW programs were minimal, and we strongly believe that these results would carry over to the more detailed analyses that we conduct in this paper. However, the more demanding nature of the specifications estimated in this paper makes it difficult to address both selectivity issues and heterogeneous effects of STW programs simultaneously, in part because addressing selection issues eliminates many observations that we can otherwise use. And finally, while the NLSY97 provides, in our view, the best available data for studying the effects of a wide array of STW programs, the data set as yet does not follow respondents very far into their careers or even all the way through their post-secondary education, but at best into their early 20's. Thus, firmer conclusions clearly await analysis five or more

\footnotetext{
${ }^{32}$ Rose (2004) presents some evidence that, for men, test score gains achieved during high school have a positive impact on post-high school earnings for those whose eighth-grade test scores were in the bottom quartile.
} 
years down the road when the NLSY97 data will permit a more detailed characterization of the developing careers of sample members. 


\section{$\underline{\text { References }}$}

Cameron, Stephen V., and James J. Heckman. 2000. "The Dynamics of Educational Attainment for Blacks, Hispanics, and Whites.” NBER Working Paper No. 7249.

Donahoe, Debra, and Marta Tienda. 1999. "Human Asset Development and the Transition from School to Work: Policy Lessons for the $21^{\text {st }}$ Century." Unpublished manuscript, Office of Population Research, Princeton University.

Falaris, Evangelos M., and H. Elizabeth Peters. 1998. "Survey Attrition and Schooling Choices." Journal of Human Resources, Vol. 33, No. 2, Spring, pp. 531-54.

Hamilton, Stephen F., and Mary A. Hamilton. 1999. Building Strong School to Work Systems: Illustrations of Key Components (Washington, DC: National School-to-Work Office).

Heckman, James, Neil Hohmann, and Jeffrey A. Smith. 2000. "Substitution and Dropout Bias in Social Experiments: A Study of an Influential Social Experiment." Quarterly Journal of Economics, Vol. 115, No. 2, pp. 651-94.

Hughes, Katherine L., Stephen F. Hamilton, and Robert J. Ivry. 2001. School-to-Work: Making a Difference in Education (New York: Institute on Education and the Economy, Teachers College, Columbia University).

Joyce, Mary, and David Neumark. 2001. "School-to-Work Programs: Information from Two Surveys." Monthly Labor Review, Vol. 124, No. 8, August, pp. 38-50.

Kemple, James J., and Jason C. Snipes. 2000. Career Academies: Impacts on Students' Engagement and Performance in High School (New York: Manpower Demonstration Research Corporation).

Kemple, James J. 2001. Career Academies: Impacts on Students' Initial Transitions to Post-Secondary Education and Employment (New York: Manpower Demonstration Research Corporation).

Kemple, James J. 2004. "Having an Impact on the Transition from School to Work: Evidence from Career Academies.” Unpublished manuscript, Manpower Demonstration Research Corporation.

Neumark, David. "Evaluating Program Effectiveness: A Case Study of the School-to-Work Opportunities Act in California." Forthcoming in Economics of Education Review.

Neumark, David, and Mary Joyce. 2001. "Evaluating School-to-Work Programs Using the New NLSY." Journal of Human Resources, Vol. 36, No. 4, Fall, pp. 666-702.

Neumark, David, and Donna Rothstein. 2003. "School-to-Career Programs and Transitions to Employment and Higher Education.” NBER Working Paper No. 10060.

Office of Technology Assessment, United States Congress. 1995. Learning to Work: Making the Transition from School to Work (Publication No. OTA-HER 637) (Washington, D.C.: U.S. Government Printing Office).

Rose, Heather. 2004. “Do Gains in Test Scores Explain Labor Market Outcomes?” Unpublished manuscript, Public Policy Institute of California. 
Stern, David. 1984. "School-Based Enterprise and the Quality of Work Experience." Youth \& Society, Vol. 15, No. 4, June, pp. 401-27.

Stern, David, Neal Finkelstein, Miguel Urquiola, and Helen Cagampang. 1997. "What Difference Does It Make If School and Work are Connected? Evidence on Co-operative Education in the United States." Economics of Education Review, Vol. 16, No. 3, June, pp. 213-29.

Stern, David, Neal Finkelstein, James R. Stone, John Latting, and Carolyn Dornsife. 1995. School to Work: Research on Programs in the United States (London and Washington: Falmer Press).

Stern, David, James Stone III, Charles Hopkins, Martin McMillion, and Robert Crain. 1994. SchoolBased Enterprise: Productive Learning in American High Schools (San Francisco: Jossey-Bass Publishers).

United States Congress. 1994. School-to-Work Opportunities Act of 1994, Public Law 103-239, 108 Stat 568, H.R. 2884.

U.S. General Accounting Office. 1990. Preparing Noncollege Youth for Employment in the U.S. and Foreign Countries (Washington, D.C.).

William T. Grant Foundation. 1988. The Forgotten Half: Pathways to Success for America's Youth and Young Families (Washington, D.C.). 
Table 1: Sample Construction and Analysis Samples

\begin{tabular}{|l|c|}
\hline \multicolumn{1}{|c|}{ Sample inclusion criteria } & Number of observations \\
\hline \multicolumn{1}{|c|}{$(1)$} & $(2)$ \\
\hline Post-high school cross-sectional analysis & 8,984 \\
\hline Total sample in 1997 & 8,609 \\
\hline Interviewed in 1999, 2000, or 2001 & 6,837 \\
\hline Age $\geq 18$ at 1999, 2000, or 2001 interview & 5,966 \\
\hline Not enrolled in high school by 1999, 2000, or 2001 interview & 4,989 \\
\hline Answered STW questions covering high school after Round 1 & 4,810 \\
\hline Complete data on baseline controls & $4,292^{*}$ \\
\hline Exclude private/vocational school students & \\
\hline Post-high school longitudinal analysis & $2,855^{*}$ \\
\hline $\begin{array}{l}\text { Followed for at least one year from September after leaving high } \\
\text { school }\end{array}$ & \\
\hline
\end{tabular}

For the post-high school enrollment/employment analysis, we use the 1999, 2000, or 2001 interview as the "post-high school interview," choosing the earliest one at which the respondent is aged 18 or older and no longer enrolled in high school. More restrictive sample inclusion criteria are imposed in each successive row. Baseline controls include race/ethnicity, education, and family structure (whether respondent lives with one, two, or no biological parents, and which ones, and household size). When other control variables are introduced in the regression models, dummy variables indicating missing data are included. For the post-high school longitudinal analysis, we use the latest data possible beginning with the September after respondents leave high school. The ' $*$ ' for the sample sizes indicates that for the analysis of different dependent variables the sample is sometimes smaller because of missing data. 
Table 2A: Linear Probability Estimates of Individual Characteristics Associated with STW Participation, Females

\begin{tabular}{|c|c|c|c|c|c|c|}
\hline & $\begin{array}{c}\text { Job } \\
\text { shadowing }\end{array}$ & Mentoring & Coop & $\begin{array}{c}\text { School } \\
\text { enterprise }\end{array}$ & Tech prep & $\begin{array}{c}\text { Internship / } \\
\text { apprenticeship }\end{array}$ \\
\hline & $(1)$ & $(2)$ & $(3)$ & $(4)$ & $(5)$ & $(6)$ \\
\hline Means & .208 & .101 & .150 & .084 & .105 & .105 \\
\hline \multicolumn{7}{|l|}{ Regression estimates } \\
\hline \multicolumn{7}{|l|}{ Demographic } \\
\hline Black & -.007 & .014 & .024 & .016 & $.078^{* * *}$ & -.007 \\
\hline Hispanic & -.036 & .012 & .004 & -.022 & .024 & .014 \\
\hline Age & .002 & -.000 & .008 & $-.019^{* * *}$ & -.007 & .012 \\
\hline \multicolumn{7}{|l|}{$\begin{array}{l}\text { Living arrangement / } \\
\text { family }\end{array}$} \\
\hline Urban & -.027 & .006 & .027 & .022 & -.022 & .008 \\
\hline $\begin{array}{l}\text { Biological parent \& step- } \\
\text { parent }\end{array}$ & -.011 & -.019 & -.024 & .032 & .005 & .005 \\
\hline Biological mother only & $-.050^{* * *}$ & -.017 & .004 & .003 & -.019 & -.021 \\
\hline Biological father only & -.048 & -.026 & .025 & -.035 & .045 & -.039 \\
\hline Other arrangement & -.020 & .023 & -.001 & -.018 & -.013 & .014 \\
\hline Household size & -.003 & $-.010^{* * *}$ & -.005 & $-.007^{*}$ & $-.010^{* * *}$ & $-.010^{* * *}$ \\
\hline Log household income & .004 & .001 & .001 & .000 & -.006 & .001 \\
\hline $\begin{array}{l}\text { Biological mother's } \\
\text { schooling }\end{array}$ & .001 & .003 & .001 & -.001 & .000 & $.005^{*}$ \\
\hline \multicolumn{7}{|l|}{ ASVAB } \\
\hline Arithmetic reasoning & .013 & -.006 & .008 & .002 & .006 & .001 \\
\hline Word knowledge & -.010 & .004 & $-.028^{*}$ & -.004 & .001 & $-.024^{*}$ \\
\hline Paragraph comprehension & .002 & -.010 & .003 & $.027^{* *}$ & -.020 & .017 \\
\hline Math knowledge & $-.036^{*}$ & .003 & -.017 & $-.023^{*}$ & -.006 & .001 \\
\hline \multicolumn{7}{|l|}{ School behaviors } \\
\hline Threatened at school & .019 & .017 & $.055^{* *}$ & .004 & .014 & -.008 \\
\hline $\begin{array}{l}\text { Got into physical fight at } \\
\text { school }\end{array}$ & -.048 & $-.062^{* * * *}$ & -.022 & -.015 & -.013 & .007 \\
\hline $\begin{array}{l}\text { Late with no excuse } 2+ \\
\text { times }\end{array}$ & -.014 & -.008 & -.021 & .027 & -.000 & .015 \\
\hline Absent $2+$ weeks & $-.049^{*}$ & -.011 & -.031 & -.030 & .026 & $-.036^{*}$ \\
\hline
\end{tabular}

Linear probability estimates are reported. There are 2,172 observations. $* * *, * *$, and $*$ indicate that the estimated coefficients are significantly different from zero at the one-, five-, or ten-percent level, respectively. Dummy variables are included for missing data on some individual variables. STW participation is measured based on responses from the 1998 interview on regarding school-to-work participation while in high school. All other variables are defined as of the first round (1997), with the exception of age, which is measured (in months) at the 1999, 2000, or 2001 interview, whichever is defined as the "post-high school interview" (see notes to Table 1). The ASVAB test scores are standardized to have mean zero and standard deviation of one for the calibration sample that took the test. The subset of ASVAB scores we use are those that make up the AFQT. Standard errors are robust to heteroscedasticity, and were adjusted to account for the clustering of observations within schools, allowing for non-independence within schools and heteroscedasticity across schools. 
Table 2B: Linear Probability Estimates of Individual Characteristics Associated with STW Participation, Males

\begin{tabular}{|c|c|c|c|c|c|c|}
\hline & $\begin{array}{c}\text { Job } \\
\text { shadowing }\end{array}$ & Mentoring & Coop & $\begin{array}{c}\text { School } \\
\text { enterprise }\end{array}$ & Tech prep & $\begin{array}{c}\text { Internship / } \\
\text { apprenticeship }\end{array}$ \\
\hline & $(1)$ & $(2)$ & $(3)$ & $(4)$ & $(5)$ & $(6)$ \\
\hline Means & .189 & .085 & .150 & .070 & .137 & .096 \\
\hline \multicolumn{7}{|l|}{ Regression estimates } \\
\hline \multicolumn{7}{|l|}{ Demographic } \\
\hline Black & -.018 & $.055^{* * * *}$ & .017 & $.048^{* * * *}$ & .032 & .019 \\
\hline Hispanic & -.015 & $.054^{* * * *}$ & -.016 & .011 & .004 & .019 \\
\hline Age & .003 & .003 & $.039^{* * * *}$ & .007 & .019 & -.003 \\
\hline \multicolumn{7}{|l|}{$\begin{array}{l}\text { Living arrangement / } \\
\text { family }\end{array}$} \\
\hline Urban & $-.067^{* *}$ & .002 & .011 & -.019 & -.025 & .010 \\
\hline $\begin{array}{l}\text { Biological parent \& step- } \\
\text { parent }\end{array}$ & -.013 & -.011 & -.011 & -.010 & -.003 & -.006 \\
\hline Biological mother only & -.034 & $-.059^{* * *}$ & -.006 & -.010 & -.012 & .007 \\
\hline Biological father only & -.053 & -.042 & -.014 & -.009 & -.008 & -.044 \\
\hline Other arrangement & -.015 & .022 & -.004 & -.018 & -.036 & .010 \\
\hline Household size & -.007 & -.006 & .004 & -.004 & .002 & -.006 \\
\hline Log household income & .000 & -.005 & -.004 & $.003^{*}$ & -.002 & -.002 \\
\hline $\begin{array}{l}\text { Biological mother's } \\
\text { schooling }\end{array}$ & .004 & .004 & -.001 & .002 & -.003 & $.004^{*}$ \\
\hline \multicolumn{7}{|l|}{ ASVAB } \\
\hline Arithmetic reasoning & .020 & -.010 & .000 & .001 & .004 & $-.023^{*}$ \\
\hline Word knowledge & -.019 & -.007 & .012 & $.036^{* * * *}$ & $.032^{* * *}$ & -.011 \\
\hline Paragraph comprehension & -.012 & .001 & -.002 & -.011 & -.018 & .002 \\
\hline Math knowledge & $-.038^{* *}$ & .010 & -.009 & -.013 & $-.024^{*}$ & $.023^{*}$ \\
\hline \multicolumn{7}{|l|}{ School behaviors } \\
\hline Threatened at school & .001 & .016 & -.006 & .006 & .022 & .023 \\
\hline $\begin{array}{l}\text { Got into physical fight at } \\
\text { school }\end{array}$ & .021 & .020 & .027 & $.041^{* *}$ & -.023 & .006 \\
\hline $\begin{array}{l}\text { Late with no excuse } 2+ \\
\text { times }\end{array}$ & .015 & -.022 & -.006 & -.004 & -.012 & -.006 \\
\hline Absent 2+ weeks & $-.055^{*}$ & $-.040^{* *}$ & $-.055^{* *}$ & -.031 & -.015 & -.033 \\
\hline
\end{tabular}

See notes to Table 2 A. There are 2,120 observations. 
Table 3: Post-High School Analysis of Effects of STW Participation on Cross-Sectional Measures of Schooling, Employment, and Training

\begin{tabular}{|c|c|c|c|c|c|c|c|}
\hline & $\begin{array}{c}\text { Any } \\
\text { college }\end{array}$ & $\begin{array}{l}\text { Currently } \\
\text { enrolled }\end{array}$ & $\begin{array}{l}\text { Attended } \\
\text { four-year }\end{array}$ & $\begin{array}{c}\text { Attended } \\
\text { two-year } \\
\text { college } \\
\end{array}$ & $\begin{array}{l}\text { Currently } \\
\text { working }\end{array}$ & $\begin{array}{l}\text { Participated } \\
\text { in training } \\
\text { program } \\
\end{array}$ & $\begin{array}{c}\text { Neither working } \\
\text { nor enrolled } \\
\text { currently }\end{array}$ \\
\hline & (1) & $(2)$ & (3) & (4) & $(5)$ & (6) & $(7)$ \\
\hline \multicolumn{8}{|l|}{ Females } \\
\hline Means & .540 & .481 & .343 & .197 & .609 & .083 & .200 \\
\hline \multicolumn{8}{|l|}{$\begin{array}{l}\text { Regression } \\
\text { estimates }\end{array}$} \\
\hline Job shadowing & $\begin{array}{c}.023 \\
(.026)\end{array}$ & $\begin{array}{l}.055^{* *} \\
(.026)\end{array}$ & $\begin{array}{l}.022 \\
(.025)\end{array}$ & $\begin{array}{l}.045^{*} \\
(.023)\end{array}$ & $\begin{array}{c}.027 \\
(.028)\end{array}$ & $\begin{array}{l}.014 \\
(.016)\end{array}$ & $\begin{array}{l}-.039^{*} \\
(.021)\end{array}$ \\
\hline Mentoring & $\begin{array}{l}.069^{* *} \\
(.034)\end{array}$ & $\begin{array}{l}.077^{* *} \\
(.033)\end{array}$ & $\begin{array}{l}.110^{* * * *} \\
(.034)\end{array}$ & $\begin{array}{l}-.042 \\
(.028)\end{array}$ & $\begin{array}{l}-.016 \\
(.036) \\
\end{array}$ & $\begin{array}{l}-.013 \\
(.020) \\
\end{array}$ & $\begin{array}{l}-.026 \\
(.028) \\
\end{array}$ \\
\hline Coop & $\begin{array}{l}-.012 \\
(.027) \\
\end{array}$ & $\begin{array}{l}-.043 \\
(.028) \\
\end{array}$ & $\begin{array}{c}-.080^{* * * *} \\
(.027)\end{array}$ & $\begin{array}{l}.068^{* * *} \\
(.027) \\
\end{array}$ & $\begin{array}{c}.034 \\
(.031) \\
\end{array}$ & $\begin{array}{c}.008 \\
(.019) \\
\end{array}$ & $\begin{array}{c}.037 \\
(.026) \\
\end{array}$ \\
\hline School enterprise & $\begin{array}{l}.056^{*} \\
(.034)\end{array}$ & $\begin{array}{c}.057 \\
(.035)\end{array}$ & $\begin{array}{c}.051 \\
(.034)\end{array}$ & $\begin{array}{c}.005 \\
(.032)\end{array}$ & $\begin{array}{c}.009 \\
(.040)\end{array}$ & $\begin{array}{c}.016 \\
(.023)\end{array}$ & $\begin{array}{l}-.041 \\
(.028)\end{array}$ \\
\hline Tech prep & $\begin{array}{l}-.064^{*} \\
(.033)\end{array}$ & $\begin{array}{l}-.044 \\
(.034)\end{array}$ & $\begin{array}{l}-.068^{* * *} \\
(.028)\end{array}$ & $\begin{array}{l}.004 \\
(.032)\end{array}$ & $\begin{array}{l}-.023 \\
(.034)\end{array}$ & $\begin{array}{l}.040^{*} \\
(.024)\end{array}$ & $\begin{array}{c}.027 \\
(.028)\end{array}$ \\
\hline $\begin{array}{l}\text { Internship / } \\
\text { apprenticeship }\end{array}$ & $\begin{array}{l}.077^{* *} \\
(.030)\end{array}$ & $\begin{array}{c}.022 \\
(.033)\end{array}$ & $\begin{array}{l}.051^{*} \\
(.029)\end{array}$ & $\begin{array}{c}.027 \\
(.029)\end{array}$ & $\begin{array}{l}-.015 \\
(.036)\end{array}$ & $\begin{array}{l}-.013 \\
(.019)\end{array}$ & $\begin{array}{c}.005 \\
(.028)\end{array}$ \\
\hline $\mathrm{N}$ & 2172 & 2172 & 2172 & 2172 & 2172 & 2134 & 2172 \\
\hline \multicolumn{8}{|l|}{ Males } \\
\hline Means & .414 & .371 & .260 & .153 & .622 & .114 & .222 \\
\hline \multicolumn{8}{|l|}{$\begin{array}{l}\text { Regression } \\
\text { estimates }\end{array}$} \\
\hline Job shadowing & $\begin{array}{l}.054^{* *} \\
(.026)\end{array}$ & $\begin{array}{l}.047^{*} \\
(.026)\end{array}$ & $\begin{array}{l}.038^{*} \\
(.023)\end{array}$ & $\begin{array}{c}.016 \\
(.022) \\
\end{array}$ & $\begin{array}{c}.005 \\
(.026)\end{array}$ & $\begin{array}{c}.009 \\
(.020)\end{array}$ & $\begin{array}{l}-.017 \\
(.022)\end{array}$ \\
\hline Mentoring & $\begin{array}{c}.057 \\
(.036)\end{array}$ & $\begin{array}{c}.027 \\
(.036)\end{array}$ & $\begin{array}{l}.070^{* *} \\
(.033)\end{array}$ & $\begin{array}{l}-.013 \\
(.030)\end{array}$ & $\begin{array}{l}-.044 \\
(.048)\end{array}$ & $\begin{array}{l}-.001 \\
(.027)\end{array}$ & $\begin{array}{l}-.013 \\
(.032)\end{array}$ \\
\hline Coop & $\begin{array}{c}.013 \\
(.029)\end{array}$ & $\begin{array}{c}.020 \\
(.029) \\
\end{array}$ & $\begin{array}{l}-.026 \\
(.024) \\
\end{array}$ & $\begin{array}{l}.038 \\
(.025) \\
\end{array}$ & $\begin{array}{l}.089^{* * * * *} \\
(.029)\end{array}$ & $\begin{array}{l}.046^{* * *} \\
(.023) \\
\end{array}$ & $\begin{array}{l}-.063^{* * *} \\
(.024)\end{array}$ \\
\hline School enterprise & $\begin{array}{l}.113^{* * * *} \\
(.036)\end{array}$ & $\begin{array}{l}.080^{* *} \\
(.037)\end{array}$ & $\begin{array}{c}.037 \\
(.035)\end{array}$ & $\begin{array}{l}.076^{* *} \\
(.035)\end{array}$ & $\begin{array}{c}.042 \\
(.041)\end{array}$ & $\begin{array}{l}-.039 \\
(.025)\end{array}$ & $\begin{array}{l}-.029 \\
(.031)\end{array}$ \\
\hline Tech prep & $\begin{array}{l}-.060^{* * *} \\
(.030)\end{array}$ & $\begin{array}{l}-.039 \\
(.029)\end{array}$ & $\begin{array}{l}-.043^{*} \\
(.025)\end{array}$ & $\begin{array}{l}-.017 \\
(.026)\end{array}$ & $\begin{array}{l}.054^{*} \\
(.030)\end{array}$ & $\begin{array}{l}.041^{*} \\
(.025)\end{array}$ & $\begin{array}{l}-.001 \\
(.026)\end{array}$ \\
\hline $\begin{array}{l}\text { Internship / } \\
\text { apprenticeship }\end{array}$ & $\begin{array}{c}.009 \\
(.035)\end{array}$ & $\begin{array}{c}.013 \\
(.035)\end{array}$ & $\begin{array}{l}-.024 \\
(.028)\end{array}$ & $\begin{array}{c}.033 \\
(.029)\end{array}$ & $\begin{array}{l}.086^{* *} \\
(.035)\end{array}$ & $\begin{array}{c}.034 \\
(.029)\end{array}$ & $\begin{array}{l}-.082^{\text {***** }} \\
(.026)\end{array}$ \\
\hline $\mathrm{N}$ & 2120 & 2120 & 2120 & 2120 & 2120 & 2080 & 2120 \\
\hline
\end{tabular}

All of the specifications include the demographic, living arrangement/family, ASVAB, and school behavior variables (see Table 2). Estimates are from linear probability models. The training programs include formal programs at schools or other centers, apprenticeships, formal company training programs, and government training programs. Standard deviations of means or standard errors of regression estimates are reported in parentheses for means. The standard errors allow for general heteroscedasticity, and were adjusted to account for the clustering of observations within schools, allowing for non-independence within schools. 
Table 4: Post-High School Analysis of Effects of STW Participation on Longitudinal Joint Work and Schooling Measures

\begin{tabular}{|c|c|c|c|c|}
\hline & $\begin{array}{l}\text { Prop. of weeks } \\
\text { in school }\end{array}$ & $\begin{array}{l}\text { Prop. of weeks } \\
\text { working }\end{array}$ & $\begin{array}{l}\text { Average hours worked } \\
\text { over all weeks }\end{array}$ & $\begin{array}{l}\text { Prop. of weeks } \\
\text { idle }\end{array}$ \\
\hline & $(1)$ & $(2)$ & (3) & (4) \\
\hline \multicolumn{5}{|l|}{ Females } \\
\hline Means & .545 & .653 & 20.21 & .156 \\
\hline \multicolumn{5}{|l|}{$\begin{array}{l}\text { Regression } \\
\text { estimates }\end{array}$} \\
\hline Job shadowing & $\begin{array}{l}-.005 \\
(.028)\end{array}$ & $\begin{array}{l}.038^{*} \\
(.022)\end{array}$ & $\begin{array}{c}.93 \\
(1.00)\end{array}$ & $\begin{array}{l}.031^{* * *} \\
(.016)\end{array}$ \\
\hline Mentoring & $\begin{array}{c}.040 \\
(.037)\end{array}$ & $\begin{array}{l}-.030 \\
(.030)\end{array}$ & $\begin{array}{l}-1.15 \\
(1.32)\end{array}$ & $\begin{array}{l}-.003 \\
(.021)\end{array}$ \\
\hline Coop & $\begin{array}{l}-.036 \\
(.028)\end{array}$ & $\begin{array}{l}.046^{*} \\
(.025)\end{array}$ & $\begin{array}{l}2.56^{* *} \\
(1.10)\end{array}$ & $\begin{array}{l}-.020 \\
(.017)\end{array}$ \\
\hline School enterprise & $\begin{array}{l}.064^{*} \\
(.037)\end{array}$ & $\begin{array}{l}-.015 \\
(.032)\end{array}$ & $\begin{array}{l}-1.21 \\
(1.20)\end{array}$ & $\begin{array}{l}-.016 \\
(.022)\end{array}$ \\
\hline Tech prep & $\begin{array}{l}-.014 \\
(.034)\end{array}$ & $\begin{array}{l}-.017 \\
(.026)\end{array}$ & $\begin{array}{c}.43 \\
(1.24)\end{array}$ & $\begin{array}{l}.018 \\
(.020)\end{array}$ \\
\hline $\begin{array}{l}\text { Internship / } \\
\text { apprenticeship }\end{array}$ & $\begin{array}{c}.033 \\
(.032)\end{array}$ & $\begin{array}{c}.013 \\
(.027)\end{array}$ & $\begin{array}{c}.69 \\
(1.20)\end{array}$ & $\begin{array}{l}-.004 \\
(.019)\end{array}$ \\
\hline $\mathrm{N}$ & 1470 & 1470 & 1420 & 1470 \\
\hline \multicolumn{5}{|l|}{ Males } \\
\hline Means & .441 & .677 & 23.75 & .154 \\
\hline \multicolumn{5}{|l|}{$\begin{array}{l}\text { Regression } \\
\text { estimates }\end{array}$} \\
\hline Job shadowing & $\begin{array}{l}.066^{* *} \\
(.028)\end{array}$ & $\begin{array}{l}.023 \\
(.024)\end{array}$ & $\begin{array}{c}.32 \\
(1.13)\end{array}$ & $\begin{array}{l}-.020 \\
(.018)\end{array}$ \\
\hline Mentoring & $\begin{array}{c}.014 \\
(.044)\end{array}$ & $\begin{array}{l}-.024 \\
(.033)\end{array}$ & $\begin{array}{c}.71 \\
(1.71)\end{array}$ & $\begin{array}{c}.021 \\
(.026)\end{array}$ \\
\hline Coop & $\begin{array}{l}-.015 \\
(.036) \\
\end{array}$ & $\begin{array}{l}.050^{* * *} \\
(.025)\end{array}$ & $\begin{array}{l}2.97^{* * *} \\
(1.32)\end{array}$ & $\begin{array}{l}-.025 \\
(.019)\end{array}$ \\
\hline School enterprise & $\begin{array}{c}.050 \\
(.046)\end{array}$ & $\begin{array}{l}.061^{*} \\
(.035)\end{array}$ & $\begin{array}{c}1.30 \\
(1.70)\end{array}$ & $\begin{array}{l}-.042^{*} \\
(.023)\end{array}$ \\
\hline Tech prep & $\begin{array}{c}.020 \\
(.036)\end{array}$ & $\begin{array}{c}.039 \\
(.028)\end{array}$ & $\begin{array}{l}2.74^{*} \\
(1.41)\end{array}$ & $\begin{array}{l}-.031 \\
(.020)\end{array}$ \\
\hline $\begin{array}{l}\text { Internship / } \\
\text { apprenticeship }\end{array}$ & $\begin{array}{l}-.011 \\
(.038)\end{array}$ & $\begin{array}{l}.086^{* * *} \\
(.030)\end{array}$ & $\begin{array}{c}3.05 \\
(1.46)\end{array}$ & $\begin{array}{l}-.040^{*} \\
(.022)\end{array}$ \\
\hline $\mathrm{N}$ & 1336 & 1337 & 1235 & 1336 \\
\hline
\end{tabular}

See notes to Table 3. All estimates are from linear regressions. The variables are based on the period beginning with the first September since leaving high school; the specifications include a control for the total number of weeks from that time until the interview. 
Table 5: Post-High School Analysis of Effects of STW Participation on Earnings, Wages, and Full-Time Status of Most Recent Job

\begin{tabular}{|c|c|c|c|c|c|}
\hline & Hourly earnings & Hourly wage & Full-time & Hourly earnings & Hourly wage \\
\hline & $(1)$ & $(2)$ & $(3)$ & $(4)$ & $(5)$ \\
\hline \multicolumn{6}{|l|}{ Females } \\
\hline Means & 2.07 & 1.97 & .440 & 2.08 & 1.97 \\
\hline \multicolumn{6}{|l|}{$\begin{array}{l}\text { Regression } \\
\text { estimates }\end{array}$} \\
\hline Job shadow & $\begin{array}{l}.049^{*} \\
(.027)\end{array}$ & $\begin{array}{c}.039 \\
(.030)\end{array}$ & $\begin{array}{c}.031 \\
(.035)\end{array}$ & $\begin{array}{c}.034 \\
(.027)\end{array}$ & $\begin{array}{c}.031 \\
(.029)\end{array}$ \\
\hline Mentoring & $\begin{array}{l}-.073^{* *} \\
(.033)\end{array}$ & $\begin{array}{l}-.028 \\
(.033) \\
\end{array}$ & $\begin{array}{l}-.097^{* * *} \\
(.049) \\
\end{array}$ & $\begin{array}{l}-.054^{*} \\
(.032) \\
\end{array}$ & $\begin{array}{l}-.016 \\
(.033) \\
\end{array}$ \\
\hline Coop & $\begin{array}{l}.051^{*} \\
(.026)\end{array}$ & $\begin{array}{c}.014 \\
(.031)\end{array}$ & $\begin{array}{c}.025 \\
(.039)\end{array}$ & $\begin{array}{c}.045 \\
(.025)\end{array}$ & $\begin{array}{c}.008 \\
(.031)\end{array}$ \\
\hline School enterprise & $\begin{array}{c}.008 \\
(.038)\end{array}$ & $\begin{array}{c}.019 \\
(.039)\end{array}$ & $\begin{array}{c}.046 \\
(.053)\end{array}$ & $\begin{array}{c}.015 \\
(.037)\end{array}$ & $\begin{array}{c}.018 \\
(.040)\end{array}$ \\
\hline Tech prep & $\begin{array}{c}.008 \\
(.035)\end{array}$ & $\begin{array}{c}.006 \\
(.038)\end{array}$ & $\begin{array}{c}.044 \\
(.047)\end{array}$ & $\begin{array}{l}-.002 \\
(.033)\end{array}$ & $\begin{array}{c}.009 \\
(.037)\end{array}$ \\
\hline $\begin{array}{l}\text { Internship / } \\
\text { apprenticeship }\end{array}$ & $\begin{array}{l}.089^{* * *} \\
(.035)\end{array}$ & $\begin{array}{l}.082^{* * *} \\
(.037)\end{array}$ & $\begin{array}{l}-.002 \\
(.043)\end{array}$ & $\begin{array}{l}.085^{\text {** }} \\
(.035)\end{array}$ & $\begin{array}{l}.095^{\text {***** }} \\
(.036)\end{array}$ \\
\hline $\mathrm{N}$ & 1264 & 1359 & 1404 & 1239 & 1331 \\
\hline \multicolumn{6}{|l|}{ Males } \\
\hline Means & 2.15 & 2.09 & .578 & 2.15 & 2.09 \\
\hline \multicolumn{6}{|l|}{$\begin{array}{l}\text { Regression } \\
\text { estimates }\end{array}$} \\
\hline Job shadow & $\begin{array}{c}.019 \\
(.033)\end{array}$ & $\begin{array}{c}.003 \\
(.033)\end{array}$ & $\begin{array}{l}.016 \\
(.039)\end{array}$ & $\begin{array}{c}.030 \\
(.032)\end{array}$ & $\begin{array}{c}.010 \\
(.032)\end{array}$ \\
\hline Mentoring & $\begin{array}{l}-.020 \\
(.052) \\
\end{array}$ & $\begin{array}{c}.012 \\
(.052) \\
\end{array}$ & $\begin{array}{l}-.017 \\
(.059) \\
\end{array}$ & $\begin{array}{l}-.008 \\
(.046) \\
\end{array}$ & $\begin{array}{c}.026 \\
(.048) \\
\end{array}$ \\
\hline Coop & $\begin{array}{l}.063^{*} \\
(.036) \\
\end{array}$ & $\begin{array}{c}.026 \\
(.036) \\
\end{array}$ & $\begin{array}{l}.073^{*} \\
(.040) \\
\end{array}$ & $\begin{array}{c}.055 \\
(.035) \\
\end{array}$ & $\begin{array}{c}.015 \\
(.036)\end{array}$ \\
\hline School enterprise & $\begin{array}{l}-.002 \\
(.051)\end{array}$ & $\begin{array}{c}.016 \\
(.048) \\
\end{array}$ & $\begin{array}{l}-.028 \\
(.062)\end{array}$ & $\begin{array}{l}-.041 \\
(.042)\end{array}$ & $\begin{array}{l}-.022 \\
(.040)\end{array}$ \\
\hline Tech prep & $\begin{array}{l}-.018 \\
(.037) \\
\end{array}$ & $\begin{array}{c}.027 \\
(.034) \\
\end{array}$ & $\begin{array}{c}.053 \\
(.043) \\
\end{array}$ & $\begin{array}{l}-.028 \\
(.035) \\
\end{array}$ & $\begin{array}{c}.015 \\
(.032) \\
\end{array}$ \\
\hline $\begin{array}{l}\text { Internship / } \\
\text { apprenticeship }\end{array}$ & $\begin{array}{c}.027 \\
(.042)\end{array}$ & $\begin{array}{c}.018 \\
(.037)\end{array}$ & $\begin{array}{c}.025 \\
(.046)\end{array}$ & $\begin{array}{c}.003 \\
(.041)\end{array}$ & $\begin{array}{l}-.007 \\
(.037)\end{array}$ \\
\hline $\begin{array}{l}\text { Condition on } \\
\text { schooling, } \\
\text { experience and } \\
\text { its square, and } \\
\text { full-time }\end{array}$ & No & No & No & Yes & Yes \\
\hline $\mathrm{N}$ & 1075 & 1160 & 1219 & 1058 & 1142 \\
\hline
\end{tabular}

See notes to Table 3. All estimates are from linear regressions. The definition of full-time is 35 or more hours per week. Earnings include tips, bonuses, overtime, etc. Earnings, wages, and full-time status are for the most recent job, for jobs held during or after the September after leaving high school. The specifications include a control for the total number of weeks since leaving high school. 
Table 6: Estimates of Equations for College Attendance

\begin{tabular}{|c|c|c|}
\hline & $\begin{array}{l}\text { College attendance, } \\
\text { females }(\mathrm{N}=2172)\end{array}$ & $\begin{array}{c}\text { College attendance, } \\
\text { males }(\mathrm{N}=2120)\end{array}$ \\
\hline & $(1)$ & $(3)$ \\
\hline Means & .573 & .455 \\
\hline \multicolumn{3}{|l|}{$\begin{array}{l}\text { Regression } \\
\text { estimates }\end{array}$} \\
\hline \multicolumn{3}{|l|}{ Demographic } \\
\hline Black & $.097^{\text {**** }}$ & $.063^{*}$ \\
\hline Hispanic & .025 & .015 \\
\hline Age & $.067^{* * * *}$ & .026 \\
\hline \multicolumn{3}{|l|}{$\begin{array}{l}\text { Living } \\
\text { arrangement / } \\
\text { family }\end{array}$} \\
\hline Urban & .029 & $.054^{*}$ \\
\hline $\begin{array}{l}\text { Biological parent } \\
\& \text { step-parent }\end{array}$ & -.023 & $-.121^{* * *}$ \\
\hline $\begin{array}{l}\text { Biological } \\
\text { mother only }\end{array}$ & $-.125^{* * *}$ & $-.125^{* * *}$ \\
\hline $\begin{array}{l}\text { Biological father } \\
\text { only }\end{array}$ & -.078 & $-.148^{* * *}$ \\
\hline $\begin{array}{l}\text { Other } \\
\text { arrangement }\end{array}$ & $-.140^{* * *}$ & $-.110^{*}$ \\
\hline Household size & -.013 & $-.020^{* *}$ \\
\hline $\begin{array}{l}\text { Log household } \\
\text { income }\end{array}$ & .002 & .014 \\
\hline $\begin{array}{l}\text { Biological } \\
\text { mother's } \\
\text { schooling }\end{array}$ & $.033^{* * * *}$ & $.040^{* * * *}$ \\
\hline \multicolumn{3}{|l|}{ ASVAB } \\
\hline $\begin{array}{l}\text { Arithmetic } \\
\text { reasoning }\end{array}$ & .002 & .008 \\
\hline Word knowledge & .034 & $.052^{* *}$ \\
\hline $\begin{array}{l}\text { Paragraph } \\
\text { comprehension }\end{array}$ & $.048^{*}$ & .029 \\
\hline Math knowledge & $.167^{* * * *}$ & $.179^{* * * *}$ \\
\hline \multicolumn{3}{|l|}{$\begin{array}{l}\text { School } \\
\text { behaviors }\end{array}$} \\
\hline $\begin{array}{l}\text { Threatened at } \\
\text { school }\end{array}$ & -.043 & $-.090^{* * * *}$ \\
\hline $\begin{array}{l}\text { Got into physical } \\
\text { fight at school }\end{array}$ & $-.156^{* * *}$ & $-.107^{* * *}$ \\
\hline $\begin{array}{l}\text { Late with no } \\
\text { excuse } 2+\text { times }\end{array}$ & -.044 & -.018 \\
\hline Absent 2+ weeks & $-.165^{\text {*** }}$ & $-.112^{* *}$ \\
\hline $\begin{array}{l}\text { Share correctly } \\
\text { predicted }\end{array}$ & .707 & .736 \\
\hline
\end{tabular}

All estimates are from probit models; partial derivatives are reported. See notes to Table 2 for additional details. The means are weighted. The specifications include a control for the total number of weeks since leaving high school. Share correctly predicted, in last row, is based on a comparison between actual outcomes and whether predicted probability of outcome is above or below median probability (weighted). Estimates reported here are for the samples in Table 3. Results were very similar for the samples used in Tables 4 and 5 (and 8 and 9 below). 
Table 7: Post-High School Analysis of Effects of STW Participation on Cross-Sectional Measures of Schooling, Employment, and Training, By Position in Distribution of Predicted Probability of College Attendance

\begin{tabular}{|c|c|c|c|c|c|c|c|}
\hline & $\begin{array}{l}\text { Any } \\
\text { college }\end{array}$ & $\begin{array}{l}\text { Currently } \\
\text { enrolled }\end{array}$ & $\begin{array}{c}\text { Attended } \\
\text { four-year } \\
\text { college }\end{array}$ & $\begin{array}{c}\text { Attended } \\
\text { two-year } \\
\text { college }\end{array}$ & $\begin{array}{l}\text { Currently } \\
\text { working }\end{array}$ & $\begin{array}{l}\text { Participated } \\
\text { in training } \\
\text { program }\end{array}$ & $\begin{array}{l}\text { Neither working nor } \\
\text { enrolled currently }\end{array}$ \\
\hline & $(1)$ & (2) & (3) & (4) & (5) & (6) & $(7)$ \\
\hline \multicolumn{8}{|l|}{ Females } \\
\hline Job shadowing & $\begin{array}{l}-.005 \\
(.003)\end{array}$ & $\begin{array}{l}.042 \\
(.036)\end{array}$ & $\begin{array}{l}-.025 \\
(.039)\end{array}$ & $\begin{array}{l}.020 \\
(.033)\end{array}$ & $\begin{array}{l}.015 \\
(.041)\end{array}$ & $\begin{array}{l}-.008 \\
(.019)\end{array}$ & $\begin{array}{l}-.002 \\
(.026)\end{array}$ \\
\hline $\mathrm{x}$ lower half & $\begin{array}{c}.005 \\
(.051)\end{array}$ & $\begin{array}{l}.027^{+} \\
(.053)\end{array}$ & $\begin{array}{c}.016 \\
(.050)\end{array}$ & $\begin{array}{l}.039^{+} \\
(.047)\end{array}$ & $\begin{array}{c}.017 \\
(.055)\end{array}$ & $\begin{array}{l}-.010 \\
(.029)\end{array}$ & $\begin{array}{c}-.066^{++} \\
(.041)\end{array}$ \\
\hline Mentoring & $\begin{array}{l}.081^{* * *} \\
(.039)\end{array}$ & $\begin{array}{l}.100^{* *} \\
(.046)\end{array}$ & $\begin{array}{l}.154^{* * * *} \\
(.048)\end{array}$ & $\begin{array}{l}-.074^{*} \\
(.041)\end{array}$ & $\begin{array}{l}-.003 \\
(.051)\end{array}$ & $\begin{array}{l}-.052^{* * *} \\
(.021)\end{array}$ & $\begin{array}{l}-.042 \\
(.029)\end{array}$ \\
\hline $\mathrm{x}$ lower half & $\begin{array}{l}-.024 \\
(.064) \\
\end{array}$ & $\begin{array}{l}-.047 \\
(.069) \\
\end{array}$ & $\begin{array}{l}-.089 \\
(.066) \\
\end{array}$ & $\begin{array}{l}.065 \\
(.060) \\
\end{array}$ & $\begin{array}{l}-.021 \\
(.071) \\
\end{array}$ & $\begin{array}{l}.073^{*} \\
(.038) \\
\end{array}$ & $\begin{array}{l}.028 \\
(.055) \\
\end{array}$ \\
\hline Coop & $\begin{array}{l}-.034 \\
(.044)\end{array}$ & $\begin{array}{l}-.051 \\
(.046)\end{array}$ & $\begin{array}{l}.135^{* * * *} \\
(.050)\end{array}$ & $\begin{array}{l}.101^{* * *} \\
(.047)\end{array}$ & $\begin{array}{l}.105^{* *} \\
(.047)\end{array}$ & $\begin{array}{l}.010 \\
(.027)\end{array}$ & $\begin{array}{l}.015 \\
(.033)\end{array}$ \\
\hline $\mathrm{x}$ lower half & $\begin{array}{c}.044 \\
(.056)\end{array}$ & $\begin{array}{c}.021 \\
(.058)\end{array}$ & $\begin{array}{l}.099^{*} \\
(.055)\end{array}$ & $\begin{array}{l}-.056 \\
(.056)\end{array}$ & $\begin{array}{l}-.118^{* * *} \\
(.058)\end{array}$ & $\begin{array}{l}-.002 \\
(.037)\end{array}$ & $\begin{array}{c}.037 \\
(.046)\end{array}$ \\
\hline School enterprise & $\begin{array}{l}.081^{*} \\
(.044)\end{array}$ & $\begin{array}{l}.095^{* *} \\
(.047)\end{array}$ & $\begin{array}{l}.103^{*} \\
(.054)\end{array}$ & $\begin{array}{l}-.022 \\
(.044)\end{array}$ & $\begin{array}{l}-.053 \\
(.062)\end{array}$ & $\begin{array}{l}.045 \\
(.034)\end{array}$ & $\begin{array}{l}-.026 \\
(.031) \\
\end{array}$ \\
\hline $\mathrm{x}$ lower half & $\begin{array}{l}-.051 \\
(.068)\end{array}$ & $\begin{array}{l}-.077 \\
(.068)\end{array}$ & $\begin{array}{l}-.091 \\
(.065)\end{array}$ & $\begin{array}{l}.041 \\
(.062)\end{array}$ & $\begin{array}{l}.112 \\
(.080)\end{array}$ & $\begin{array}{l}-.052 \\
(.046)\end{array}$ & $\begin{array}{l}-.018 \\
(.055)\end{array}$ \\
\hline Tech prep & $\begin{array}{l}-.029 \\
(.050) \\
\end{array}$ & $\begin{array}{l}-.006 \\
(.054) \\
\end{array}$ & $\begin{array}{l}-.105^{*} \\
(.056) \\
\end{array}$ & $\begin{array}{c}.076 \\
(.050) \\
\end{array}$ & $\begin{array}{c}.009 \\
(.054) \\
\end{array}$ & $\begin{array}{c}.047 \\
(.036) \\
\end{array}$ & $\begin{array}{l}-.025 \\
(.032) \\
\end{array}$ \\
\hline $\mathrm{x}$ lower half & $\begin{array}{l}-.053^{++} \\
(.063)\end{array}$ & $\begin{array}{l}-.059 \\
(.067)\end{array}$ & $\begin{array}{c}.062 \\
(.062)\end{array}$ & $\begin{array}{l}-.115^{* *} \\
(.057)\end{array}$ & $\begin{array}{l}-.045 \\
(.072)\end{array}$ & $\begin{array}{l}-.013 \\
(.046)\end{array}$ & $\begin{array}{c}.080 \\
(.051)\end{array}$ \\
\hline $\begin{array}{l}\text { Internship / } \\
\text { apprenticeship }\end{array}$ & $\begin{array}{l}.083^{* *} \\
(.037) \\
\end{array}$ & $\begin{array}{l}.004 \\
(.045) \\
\end{array}$ & $\begin{array}{l}.093^{* *} \\
(.044) \\
\end{array}$ & $\begin{array}{l}-.010 \\
(.039) \\
\end{array}$ & $\begin{array}{l}-.022 \\
(.050) \\
\end{array}$ & $\begin{array}{c}.002 \\
(.024) \\
\end{array}$ & $\begin{array}{l}.018 \\
(.032) \\
\end{array}$ \\
\hline $\mathrm{x}$ lower half & $\begin{array}{l}-.014 \\
(.062)\end{array}$ & $\begin{array}{l}.036 \\
(.065)\end{array}$ & $\begin{array}{l}-.083 \\
(.058)\end{array}$ & $\begin{array}{l}.069 \\
(.059)\end{array}$ & $\begin{array}{l}.008 \\
(.054)\end{array}$ & $\begin{array}{l}-.028 \\
(.037)\end{array}$ & $\begin{array}{l}-.022 \\
(.055)\end{array}$ \\
\hline \multicolumn{8}{|l|}{ Males } \\
\hline Job shadowing & $\begin{array}{l}.116^{* * * *} \\
(.044)\end{array}$ & $\begin{array}{l}.098^{* *} \\
(.044)\end{array}$ & $\begin{array}{c}.061 \\
(.046)\end{array}$ & $\begin{array}{c}.056 \\
(.036)\end{array}$ & $\begin{array}{c}.041 \\
(.044)\end{array}$ & $\begin{array}{l}-.012 \\
(.031)\end{array}$ & $\begin{array}{l}.017 \\
(.029)\end{array}$ \\
\hline $\mathrm{x}$ lower half & $\begin{array}{l}-.101 \\
(.053)\end{array}$ & $\begin{array}{l}-.082 \\
(.052)\end{array}$ & $\begin{array}{l}-.036 \\
(.052)\end{array}$ & $\begin{array}{l}-.065 \\
(.043)\end{array}$ & $\begin{array}{l}-.060 \\
(.059)\end{array}$ & $\begin{array}{c}.036 \\
(.040)\end{array}$ & $\begin{array}{l}-.000 \\
(.046)\end{array}$ \\
\hline Mentoring & $\begin{array}{l}-.013 \\
(.054)\end{array}$ & $\begin{array}{l}-.046 \\
(.057)\end{array}$ & $\begin{array}{l}.056 \\
(.055)\end{array}$ & $\begin{array}{l}-.069^{*} \\
(.042)\end{array}$ & $\begin{array}{l}-.081 \\
(.055)\end{array}$ & $\begin{array}{l}.030 \\
(.042)\end{array}$ & $\begin{array}{l}-.021 \\
(.035)\end{array}$ \\
\hline $\mathrm{x}$ lower half & $\begin{array}{l}.126^{*,++} \\
(.075)\end{array}$ & $\begin{array}{l}.134^{*,+} \\
(.077)\end{array}$ & $\begin{array}{l}.021^{++} \\
(.068)\end{array}$ & $\begin{array}{l}.105^{*} \\
(.062)\end{array}$ & $\begin{array}{c}.068 \\
(.078)\end{array}$ & $\begin{array}{l}-.061 \\
(.054)\end{array}$ & $\begin{array}{c}.013 \\
(.061)\end{array}$ \\
\hline Coop & $\begin{array}{c}-.102^{* * *} \\
(.046)\end{array}$ & $\begin{array}{c}-.121^{* * *} \\
(.048)\end{array}$ & $\begin{array}{l}-.109^{* * *} \\
(.044)\end{array}$ & $\begin{array}{c}.008 \\
(.038)\end{array}$ & $\begin{array}{l}.118^{* * * * *} \\
(.045)\end{array}$ & $\begin{array}{l}.066^{*} \\
(.036)\end{array}$ & $\begin{array}{l}-.000 \\
(.032)\end{array}$ \\
\hline $\mathrm{x}$ lower half & $\begin{array}{c}.197^{* * * *+++} \\
(.058)\end{array}$ & $\begin{array}{c}.245^{* * *,+++} \\
(.060)\end{array}$ & $\begin{array}{l}.147^{* * * * *} \\
(.051)\end{array}$ & $\begin{array}{l}.050^{+} \\
(.049)\end{array}$ & $\begin{array}{l}-.052^{+} \\
(.059)\end{array}$ & $\begin{array}{l}-.034 \\
(.047)\end{array}$ & $\begin{array}{c}-.105^{* *,+++} \\
(.047)\end{array}$ \\
\hline School enterprise & $\begin{array}{l}.143^{* * * *} \\
(.054)\end{array}$ & $\begin{array}{l}.107^{*} \\
(.059)\end{array}$ & $\begin{array}{l}.092 \\
(.063)\end{array}$ & $\begin{array}{l}.051 \\
(.051)\end{array}$ & $\begin{array}{l}.083 \\
(.061)\end{array}$ & $\begin{array}{l}-.113^{* * *} \\
(.025)\end{array}$ & $\begin{array}{c}-.042 \\
(.038)\end{array}$ \\
\hline $\mathrm{x}$ lower half & $\begin{array}{l}-.045^{++} \\
(.072)\end{array}$ & $\begin{array}{l}-.039 \\
(.075)\end{array}$ & $\begin{array}{l}-.091 \\
(.072)\end{array}$ & $\begin{array}{l}.046^{++} \\
(.071)\end{array}$ & $\begin{array}{l}-.077 \\
(.082)\end{array}$ & $\begin{array}{c}.129 \\
(.046)\end{array}$ & $\begin{array}{c}.020 \\
(.061)\end{array}$ \\
\hline Tech prep & $\begin{array}{l}-134^{* * * * *} \\
(.051)\end{array}$ & $\begin{array}{l}-.095^{*} \\
(.050)\end{array}$ & $\begin{array}{l}-.104^{* * *} \\
(.048)\end{array}$ & $\begin{array}{l}-.030 \\
(.042)\end{array}$ & $\begin{array}{l}.085^{*} \\
(.049)\end{array}$ & $\begin{array}{l}.084^{* * *} \\
(.043)\end{array}$ & $\begin{array}{c}.023 \\
(.038)\end{array}$ \\
\hline $\mathrm{x}$ lower half & $\begin{array}{l}.118^{*} \\
(.061)\end{array}$ & $\begin{array}{l}.087 \\
(.060)\end{array}$ & $\begin{array}{l}.101^{*} \\
(.054)\end{array}$ & $\begin{array}{c}.017 \\
(.050)\end{array}$ & $\begin{array}{l}-.051 \\
(.063)\end{array}$ & $\begin{array}{l}-.066 \\
(.050)\end{array}$ & $\begin{array}{l}-.036 \\
(.053)\end{array}$ \\
\hline $\begin{array}{l}\text { Internship / } \\
\text { apprenticeship }\end{array}$ & $\begin{array}{l}-.034 \\
(.054)\end{array}$ & $\begin{array}{l}.005 \\
(.054)\end{array}$ & $\begin{array}{l}.035 \\
(.052) \\
\end{array}$ & $\begin{array}{l}-.068^{*} \\
(.041) \\
\end{array}$ & $\begin{array}{l}.025 \\
(.053) \\
\end{array}$ & $\begin{array}{l}.033 \\
(.040)\end{array}$ & $\begin{array}{l}-.052^{*} \\
(.031) \\
\end{array}$ \\
\hline x lower half & $\begin{array}{l}.070 \\
(.070)\end{array}$ & $\begin{array}{l}.005 \\
(.067)\end{array}$ & $\begin{array}{c}-.106^{*,++} \\
(.057)\end{array}$ & $\begin{array}{c}.176^{* * * *,++} \\
(.061)\end{array}$ & $\begin{array}{l}.111^{+++} \\
(.072)\end{array}$ & $\begin{array}{l}.003 \\
(.054)\end{array}$ & $\begin{array}{c}-.049^{+++} \\
(.049)\end{array}$ \\
\hline
\end{tabular}

See notes to Tables 3 and 6 . In constructing the lower half of the distribution of predicted probabilities of college attendance, the weighted median of the predicted probability of college attendance based on the model in Table 6 is used. ***,**, and * indicate that the estimated coefficients are significantly different from zero at the one-, five-, or ten-percent level, respectively. For the interactions with the lower half,,+++++ , and + indicate that the overall effects for the lower half (the sums of the main and interactive effects) are significantly different from zero at the one-, five-, or ten-percent level, respectively. 
Table 8: Post-High School Analysis of Effects of STW Participation on Longitudinal Joint Work and Schooling Measures, By Position in Distribution of Predicted Probability of College Attendance

\begin{tabular}{|c|c|c|c|c|}
\hline & $\begin{array}{l}\text { Prop. of weeks } \\
\text { in school }\end{array}$ & $\begin{array}{l}\text { Prop. of weeks } \\
\text { working }\end{array}$ & $\begin{array}{c}\text { Average hours worked } \\
\text { over all weeks }\end{array}$ & $\begin{array}{c}\text { Prop. of } \\
\text { weeks idle }\end{array}$ \\
\hline & $(1)$ & (2) & (3) & (4) \\
\hline \multicolumn{5}{|l|}{ Females } \\
\hline Job shadowing & $\begin{array}{c}-.046 \\
(.038) \\
\end{array}$ & $\begin{array}{c}.041 \\
(.032) \\
\end{array}$ & $\begin{array}{c}1.02 \\
(1.32) \\
\end{array}$ & $\begin{array}{l}-.024^{*} \\
(.013)\end{array}$ \\
\hline $\mathrm{x}$ lower half & $\begin{array}{c}.066 \\
(.054)\end{array}$ & $\begin{array}{l}-.005 \\
(.046)\end{array}$ & $\begin{array}{c}-.04 \\
(1.99)\end{array}$ & $\begin{array}{l}-.012 \\
(.030)\end{array}$ \\
\hline Mentoring & $\begin{array}{c}.059 \\
(.047)\end{array}$ & $\begin{array}{l}-.019 \\
(.046)\end{array}$ & $\begin{array}{c}.98 \\
(1.81)\end{array}$ & $\begin{array}{l}-.008 \\
(.016)\end{array}$ \\
\hline $\mathrm{x}$ lower half & $\begin{array}{l}-.033 \\
(.065)\end{array}$ & $\begin{array}{l}-.018 \\
(.062)\end{array}$ & $\begin{array}{c}-.26 \\
(2.49)\end{array}$ & $\begin{array}{c}.009 \\
(.039)\end{array}$ \\
\hline Coop & $\begin{array}{c}.034 \\
(.047)\end{array}$ & $\begin{array}{l}.072^{*} \\
(.040) \\
\end{array}$ & $\begin{array}{c}2.41 \\
(1.66)\end{array}$ & $\begin{array}{c}.017 \\
(.019) \\
\end{array}$ \\
\hline $\mathrm{x}$ lower half & $\begin{array}{c}-.001 \\
(.064)\end{array}$ & $\begin{array}{c}-.042 \\
(.050)\end{array}$ & $\begin{array}{c}.37^{+} \\
(2.17)\end{array}$ & $\begin{array}{l}-.003 \\
(.031)\end{array}$ \\
\hline School enterprise & $\begin{array}{l}.113^{* *} \\
(.048)\end{array}$ & $\begin{array}{l}-.068 \\
(.046)\end{array}$ & $\begin{array}{l}-3.25^{* *} \\
(1.47)\end{array}$ & $\begin{array}{l}-.025 \\
(.017)\end{array}$ \\
\hline $\mathrm{x}$ lower half & $\begin{array}{c}-.083 \\
(.068)\end{array}$ & $\begin{array}{c}.086 \\
(.062)\end{array}$ & $\begin{array}{c}3.37 \\
(2.24)\end{array}$ & $\begin{array}{c}.017 \\
(.039)\end{array}$ \\
\hline Tech prep & $\begin{array}{l}-.054 \\
(.052)\end{array}$ & $\begin{array}{l}.028 \\
(.047)\end{array}$ & $\begin{array}{c}2.12 \\
(2.00)\end{array}$ & $\begin{array}{l}.013 \\
(.027)\end{array}$ \\
\hline $\mathrm{x}$ lower half & $\begin{array}{c}.065 \\
(.069)\end{array}$ & $\begin{array}{l}-.067 \\
(.058)\end{array}$ & $\begin{array}{l}-2.67 \\
(2.32)\end{array}$ & $\begin{array}{c}.007 \\
(.040)\end{array}$ \\
\hline $\begin{array}{l}\text { Internship / } \\
\text { apprenticeship }\end{array}$ & $\begin{array}{c}.021 \\
(.039)\end{array}$ & $\begin{array}{c}.010 \\
(.042)\end{array}$ & $\begin{array}{c}1.15 \\
(1.81)\end{array}$ & $\begin{array}{c}.013 \\
(.022)\end{array}$ \\
\hline x lower half & $\begin{array}{c}.030 \\
(.063) \\
\end{array}$ & $\begin{array}{c}.002 \\
(.057) \\
\end{array}$ & $\begin{array}{l}-1.13 \\
(2.45) \\
\end{array}$ & $\begin{array}{c}.032 \\
(.038) \\
\end{array}$ \\
\hline \multicolumn{5}{|l|}{ Males } \\
\hline Job shadowing & $\begin{array}{l}.079^{*} \\
(.044)\end{array}$ & $\begin{array}{c}.056 \\
(.039)\end{array}$ & $\begin{array}{c}1.09 \\
(1.65)\end{array}$ & $\begin{array}{c}-.023 \\
(.019)\end{array}$ \\
\hline $\mathrm{x}$ lower half & $\begin{array}{l}-.018^{+} \\
(.056)\end{array}$ & $\begin{array}{c}-.056 \\
(.049) \\
\end{array}$ & $\begin{array}{l}-2.49 \\
(2.17) \\
\end{array}$ & $\begin{array}{c}.003 \\
(.031) \\
\end{array}$ \\
\hline Mentoring & $\begin{array}{l}-.010 \\
(.059)\end{array}$ & $\begin{array}{l}-.020 \\
(.048)\end{array}$ & $\begin{array}{c}.07 \\
(2.26)\end{array}$ & $\begin{array}{c}.011 \\
(.029)\end{array}$ \\
\hline $\mathrm{x}$ lower half & $\begin{array}{c}.048 \\
(.082)\end{array}$ & $\begin{array}{l}-.008 \\
(.070)\end{array}$ & $\begin{array}{c}.86 \\
(3.48)\end{array}$ & $\begin{array}{c}.014 \\
(.050)\end{array}$ \\
\hline Coop & $\begin{array}{l}-.107^{* * *} \\
(.051)\end{array}$ & $\begin{array}{l}.089^{* * *} \\
(.041) \\
\end{array}$ & $\begin{array}{l}6.29^{* * * *} \\
(1.89)\end{array}$ & $\begin{array}{c}.007 \\
(.025) \\
\end{array}$ \\
\hline $\mathrm{x}$ lower half & $\begin{array}{l}.147^{* *} \\
(.067)\end{array}$ & $\begin{array}{l}-.064 \\
(.052)\end{array}$ & $\begin{array}{l}-5.34^{* * *} \\
(2.55)\end{array}$ & $\begin{array}{l}-.051 \\
(.037)\end{array}$ \\
\hline School enterprise & $\begin{array}{c}.047 \\
(.064)\end{array}$ & $\begin{array}{c}.021 \\
(.049)\end{array}$ & $\begin{array}{c}-.72 \\
(2.27)\end{array}$ & $\begin{array}{c}.013 \\
(.031)\end{array}$ \\
\hline $\mathrm{x}$ lower half & $\begin{array}{c}.032 \\
(.094)\end{array}$ & $\begin{array}{l}.060^{+} \\
(.068)\end{array}$ & $\begin{array}{c}2.87 \\
(3.31)\end{array}$ & $\begin{array}{c}-.106^{* *,++} \\
(.045) \\
\end{array}$ \\
\hline Tech prep & $\begin{array}{c}-.069 \\
(.060)\end{array}$ & $\begin{array}{l}.090^{* *} \\
(.042)\end{array}$ & $\begin{array}{l}5.56^{* *} \\
(2.47)\end{array}$ & $\begin{array}{l}-.018 \\
(.023)\end{array}$ \\
\hline $\mathrm{x}$ lower half & $\begin{array}{l}.137^{*} \\
(.073)\end{array}$ & $\begin{array}{l}-.075 \\
(.052)\end{array}$ & $\begin{array}{l}-4.03 \\
(2.84)\end{array}$ & $\begin{array}{l}-.020 \\
(.035)\end{array}$ \\
\hline $\begin{array}{l}\text { Internship / } \\
\text { apprenticeship }\end{array}$ & $\begin{array}{l}-.033 \\
(.059)\end{array}$ & $\begin{array}{l}.048 \\
(.045)\end{array}$ & $\begin{array}{c}3.28 \\
(2.09)\end{array}$ & $\begin{array}{l}-.026 \\
(.028)\end{array}$ \\
\hline $\mathrm{x}$ lower half & $\begin{array}{c}.042 \\
(.074)\end{array}$ & $\begin{array}{l}.066^{+++} \\
(.058)\end{array}$ & $\begin{array}{c}-.48 \\
(2.78)\end{array}$ & $\begin{array}{l}-.028^{+} \\
(.042)\end{array}$ \\
\hline
\end{tabular}

See notes to Tables $3,4,6$, and 7 . 
Table 9: Post-High School Analysis of Effects of STW Participation on Earnings, Wages, and Full-Time Status of Most Recent Job, By Position in Distribution of Predicted Probability of College Attendance

\begin{tabular}{|c|c|c|c|c|c|}
\hline & Hourly earnings & Hourly wage & Full-time & Hourly earnings & Hourly wage \\
\hline & $(1)$ & (2) & (3) & (4) & (5) \\
\hline \multicolumn{6}{|l|}{ Females } \\
\hline Job shadowing & $\begin{array}{l}.083^{*} \\
(.043)\end{array}$ & $\begin{array}{l}.062 \\
(.045)\end{array}$ & $\begin{array}{l}-.012 \\
(.052)\end{array}$ & $\begin{array}{l}.070 \\
(.043)\end{array}$ & $\begin{array}{l}.068 \\
(.044)\end{array}$ \\
\hline $\mathrm{x}$ lower half & $\begin{array}{l}-.061 \\
(.057)\end{array}$ & $\begin{array}{l}-.042 \\
(.062)\end{array}$ & $\begin{array}{c}.085 \\
(.073)\end{array}$ & $\begin{array}{l}-.064 \\
(.056)\end{array}$ & $\begin{array}{l}-.066 \\
(.060)\end{array}$ \\
\hline Mentoring & $\begin{array}{l}-.146^{* * * *} \\
(.046)\end{array}$ & $\begin{array}{l}-.085 \\
(.054)\end{array}$ & $\begin{array}{l}-.080 \\
(.071)\end{array}$ & $\begin{array}{l}-.125^{* * * *} \\
(.046)\end{array}$ & $\begin{array}{l}-.082 \\
(.055)\end{array}$ \\
\hline $\mathrm{x}$ lower half & $\begin{array}{l}.134 \\
(.066)\end{array}$ & $\begin{array}{l}.106 \\
(.072)\end{array}$ & $\begin{array}{l}-.025 \\
(.097)\end{array}$ & $\begin{array}{l}.127^{*} \\
(.067)\end{array}$ & $\begin{array}{l}.117 \\
(.074)\end{array}$ \\
\hline Coop & $\begin{array}{l}.075^{*} \\
(.045)\end{array}$ & $\begin{array}{c}.051 \\
(.051)\end{array}$ & $\begin{array}{l}-.061 \\
(.060)\end{array}$ & $\begin{array}{l}.063 \\
(.044)\end{array}$ & $\begin{array}{l}.041 \\
(.052)\end{array}$ \\
\hline $\mathrm{x}$ lower half & $\begin{array}{l}-.043 \\
(.055)\end{array}$ & $\begin{array}{l}-.065 \\
(.064)\end{array}$ & $\begin{array}{l}.137^{*} \\
(.078)\end{array}$ & $\begin{array}{l}-.033 \\
(.055)\end{array}$ & $\begin{array}{l}-.057 \\
(.066)\end{array}$ \\
\hline School enterprise & $\begin{array}{l}-.051 \\
(.066)\end{array}$ & $\begin{array}{c}.019 \\
(.065)\end{array}$ & $\begin{array}{c}.029 \\
(.080)\end{array}$ & $\begin{array}{l}-.018 \\
.0670 \\
\end{array}$ & $\begin{array}{l}.036 \\
(.068) \\
\end{array}$ \\
\hline $\mathrm{x}$ lower half & $\begin{array}{l}.098 \\
(.084)\end{array}$ & $\begin{array}{l}-.001 \\
(.085)\end{array}$ & $\begin{array}{l}.019 \\
(.107)\end{array}$ & $\begin{array}{l}.054 \\
(.084)\end{array}$ & $\begin{array}{l}-.032 \\
(.087)\end{array}$ \\
\hline Tech prep & $\begin{array}{l}.081 \\
(.058)\end{array}$ & $\begin{array}{l}.036 \\
(.075)\end{array}$ & $\begin{array}{l}.106 \\
(.083)\end{array}$ & $\begin{array}{l}.040 \\
(.055)\end{array}$ & $\begin{array}{l}.033 \\
(.070)\end{array}$ \\
\hline x lower half & $\begin{array}{l}-.109 \\
(.071)\end{array}$ & $\begin{array}{l}-.044 \\
(.081)\end{array}$ & $\begin{array}{l}-.110 \\
(.099)\end{array}$ & $\begin{array}{l}-.060 \\
(.069)\end{array}$ & $\begin{array}{l}-.034 \\
(.078)\end{array}$ \\
\hline $\begin{array}{l}\text { Internship / } \\
\text { apprenticeship }\end{array}$ & $\begin{array}{c}.082 \\
(.059)\end{array}$ & $\begin{array}{c}.062 \\
(.059)\end{array}$ & $\begin{array}{l}-.033 \\
(.059)\end{array}$ & $\begin{array}{c}.081 \\
(.059)\end{array}$ & $\begin{array}{c}.086 \\
(.058)\end{array}$ \\
\hline $\mathrm{x}$ lower half & $\begin{array}{l}.012^{++} \\
(.071)\end{array}$ & $\begin{array}{l}.043^{++} \\
(.074)\end{array}$ & $\begin{array}{c}.040 \\
(.086)\end{array}$ & $\begin{array}{l}.010^{++} \\
(.071)\end{array}$ & $\begin{array}{l}.025^{++} \\
(.073)\end{array}$ \\
\hline \multicolumn{6}{|l|}{ Males } \\
\hline Job shadowing & $\begin{array}{l}-.023 \\
(.049)\end{array}$ & $\begin{array}{l}-.029 \\
(.053)\end{array}$ & $\begin{array}{c}.035 \\
(.065)\end{array}$ & $\begin{array}{l}-.019 \\
(.049)\end{array}$ & $\begin{array}{l}-.027 \\
(.031)\end{array}$ \\
\hline $\mathrm{x}$ lower half & $\begin{array}{c}.073 \\
(.063)\end{array}$ & $\begin{array}{c}.050 \\
(.063)\end{array}$ & $\begin{array}{l}-.086 \\
(.083)\end{array}$ & $\begin{array}{c}.084 \\
(.066)\end{array}$ & $\begin{array}{l}.061 \\
(.064)\end{array}$ \\
\hline Mentoring & $\begin{array}{l}-.005 \\
(.077)\end{array}$ & $\begin{array}{c}.063 \\
(.083)\end{array}$ & $\begin{array}{l}-.026 \\
(.078)\end{array}$ & $\begin{array}{c}.034 \\
(.064)\end{array}$ & $\begin{array}{l}.099 \\
(.074)\end{array}$ \\
\hline $\mathrm{x}$ lower half & $\begin{array}{l}-.025 \\
(.088)\end{array}$ & $\begin{array}{l}-.092 \\
(.091)\end{array}$ & $\begin{array}{l}.001 \\
(.107)\end{array}$ & $\begin{array}{l}-.078 \\
(.088)\end{array}$ & $\begin{array}{l}-.131 \\
(.092)\end{array}$ \\
\hline Coop & $\begin{array}{c}.070 \\
(.061)\end{array}$ & $\begin{array}{c}.036 \\
(.061)\end{array}$ & $\begin{array}{l}.126^{*} \\
(.065)\end{array}$ & $\begin{array}{l}.045 \\
(.057)\end{array}$ & $\begin{array}{l}.009 \\
(.059)\end{array}$ \\
\hline $\mathrm{x}$ lower half & $\begin{array}{l}-.021 \\
(.076)\end{array}$ & $\begin{array}{l}-.024 \\
(.077)\end{array}$ & $\begin{array}{l}-.088 \\
(.084)\end{array}$ & $\begin{array}{l}.008 \\
(.075)\end{array}$ & $\begin{array}{l}.003 \\
(.076)\end{array}$ \\
\hline School enterprise & $\begin{array}{l}.065 \\
(.082)\end{array}$ & $\begin{array}{l}.089 \\
(.081)\end{array}$ & $\begin{array}{l}-.072 \\
(.090)\end{array}$ & $\begin{array}{l}-.006 \\
(.060)\end{array}$ & $\begin{array}{l}.032 \\
(.064)\end{array}$ \\
\hline $\mathrm{x}$ lower half & $\begin{array}{l}-.113 \\
(.102)\end{array}$ & $\begin{array}{l}-.135 \\
(.096)\end{array}$ & $\begin{array}{c}.070 \\
(.120)\end{array}$ & $\begin{array}{l}-.054 \\
(.085)\end{array}$ & $\begin{array}{l}-.095 \\
(.081)\end{array}$ \\
\hline Tech prep & $\begin{array}{l}-.059 \\
(.069)\end{array}$ & $\begin{array}{c}.016 \\
(.066)\end{array}$ & $\begin{array}{c}.071 \\
(.075)\end{array}$ & $\begin{array}{l}-.062 \\
(.064)\end{array}$ & $\begin{array}{l}.008 \\
(.061)\end{array}$ \\
\hline $\mathrm{x}$ lower half & $\begin{array}{l}.065 \\
(.080)\end{array}$ & $\begin{array}{l}.022 \\
(.076)\end{array}$ & $\begin{array}{l}-.027 \\
(.091)\end{array}$ & $\begin{array}{l}.057 \\
(.077)\end{array}$ & $\begin{array}{l}.018 \\
(.072)\end{array}$ \\
\hline $\begin{array}{l}\text { Internship / } \\
\text { apprenticeship }\end{array}$ & $\begin{array}{c}.030 \\
(.075)\end{array}$ & $\begin{array}{l}-.053 \\
(.069)\end{array}$ & $\begin{array}{c}.042 \\
(.071)\end{array}$ & $\begin{array}{l}-.001 \\
(.072)\end{array}$ & $\begin{array}{l}-.087 \\
(.065)\end{array}$ \\
\hline $\mathrm{x}$ lower half & $\begin{array}{l}-.005 \\
(.089)\end{array}$ & $\begin{array}{c}.122 \\
(.083)\end{array}$ & $\begin{array}{l}-.029 \\
(.092)\end{array}$ & $\begin{array}{c}.007 \\
(.086)\end{array}$ & $\begin{array}{l}.136^{*} \\
(.080)\end{array}$ \\
\hline Conditional & No & No & No & Yes & Yes \\
\hline
\end{tabular}

See notes to Tables $3,5,6$, and 7 . 
Table 10: Summary of Differences in Effects of STW Participation

\begin{tabular}{|c|c|c|c|c|}
\hline & $\begin{array}{l}\text { Schooling-related, } \\
\text { Forgotten Half }\end{array}$ & $\begin{array}{c}\text { Schooling-related, } \\
\text { top half }\end{array}$ & $\begin{array}{c}\text { Job-related, } \\
\text { Forgotten Half }\end{array}$ & $\begin{array}{l}\text { Job-related, } \\
\text { top half }\end{array}$ \\
\hline & $(1)$ & (2) & (3) & (4) \\
\hline \multicolumn{5}{|l|}{ Females } \\
\hline Job shadowing & $\begin{array}{l}\text { Currently enrolled: + } \\
\text { Attended 2-year college: + }\end{array}$ & & Idle: -- & $\begin{array}{l}\text { Weeks idle: - } \\
\text { Earnings, uncond.: + }\end{array}$ \\
\hline Mentoring & & $\begin{array}{l}\text { Any college: }++ \\
\text { Currently enrolled: }++ \\
\text { Attended 4-year college: }+++ \\
\text { Attended 2-year college: - }\end{array}$ & & $\begin{array}{l}\text { Training: -- } \\
\text { Earnings, uncond.: ---- } \\
\text { Earning, cond.: ---- }\end{array}$ \\
\hline Coop & & $\begin{array}{l}\text { Attended 4-year college: --- } \\
\text { Attended 2-year college: }++\end{array}$ & Hours: + & $\begin{array}{l}\text { Currently working: ++ } \\
\text { Weeks working: + } \\
\text { Earnings, uncond.: + }\end{array}$ \\
\hline $\begin{array}{l}\text { School } \\
\text { enterprise }\end{array}$ & & $\begin{array}{l}\text { Any college: }+ \\
\text { Currently enrolled: }++ \\
\text { Attended 4-year college: + } \\
\text { Weeks in school: }++\end{array}$ & & Hours: -- \\
\hline Tech prep & Any college: -- & Attended 4-year college: - & & \\
\hline $\begin{array}{l}\text { Internship/ } \\
\text { apprenticeship }\end{array}$ & & $\begin{array}{l}\text { Any college: }++ \\
\text { Attended 4-year college: ++ }\end{array}$ & $\begin{array}{l}\text { Earnings, uncond.: ++ } \\
\text { Wage, uncond.: ++ } \\
\text { Earnings, cond.: ++ } \\
\text { Wage, cond.: ++ } \\
\end{array}$ & \\
\hline \multicolumn{5}{|l|}{ Males } \\
\hline Job shadowing & Weeks in school: + & $\begin{array}{l}\text { Any college: }+++ \\
\text { Currently enrolled: ++ } \\
\text { Weeks in school: }+\end{array}$ & & \\
\hline Mentoring & $\begin{array}{l}\text { Any college: }++ \\
\text { Currently enrolled: } \\
\text { Attended 4-year college: }++\end{array}$ & Attended 2-year college: - & & \\
\hline Coop & $\begin{array}{l}\text { Any college: }+++ \\
\text { Currently enrolled: }+++ \\
\text { Attended 2-year college: }+ \\
\text { Weeks in school: -- }\end{array}$ & $\begin{array}{l}\text { Any college: -- } \\
\text { Currently enrolled: -- } \\
\text { Attended 4-year college: -- } \\
\text { Weeks in school: -- }\end{array}$ & $\begin{array}{l}\text { Currently working: + } \\
\text { Idle: --- }\end{array}$ & $\begin{array}{l}\text { Currently working: +++ } \\
\text { Training: + } \\
\text { Weeks working: ++ } \\
\text { Hours: +++ } \\
\text { Full-time: + }\end{array}$ \\
\hline $\begin{array}{l}\text { School } \\
\text { enterprise }\end{array}$ & $\begin{array}{l}\text { Any college: }++ \\
\text { Attended 2-year college: ++ }\end{array}$ & $\begin{array}{l}\text { Any college: }+++ \\
\text { Currently enrolled: }+\end{array}$ & $\begin{array}{l}\text { Weeks working: + } \\
\text { Weeks idle: -- }\end{array}$ & Training: -- \\
\hline Tech prep & & $\begin{array}{l}\text { Any college: --- } \\
\text { Currently enrolled: - } \\
\text { Attended 4-year college: -- }\end{array}$ & & $\begin{array}{l}\text { Currently working: + } \\
\text { Training: ++ } \\
\text { Weeks working: ++ } \\
\text { Hours: ++ }\end{array}$ \\
\hline $\begin{array}{l}\text { Internship/ } \\
\text { apprenticeship }\end{array}$ & $\begin{array}{l}\text { Attended 4-year college: } \\
\text { Attended 2-year college: }\end{array}$ & Attended 2-year college: - & $\begin{array}{l}\text { Currently working: +++ } \\
\text { Idle: --- } \\
\text { Weeks working: +++ } \\
\text { Weeks idle: - }\end{array}$ & Idle: - \\
\hline
\end{tabular}

Results are from Tables 7-9. The sign is as indicated, appearing three, two, or one, times to indicate that the estimate is significantly different from zero at the one-, five-, or ten-percent level, respectively. In columns (1) and (3), entries appearing in bold are statistically significant at the ten-percent level or better only for the forgotten half (or significant with the opposite sign). Those underlined as well are significantly different from the effects for those in the rest of the distribution, at the ten-percent level or better. 